\title{
nam \\ Ochratoxin A in Slaughtered Pigs and Pork Products
}

\author{
Mikela Vlachou, Andreana Pexara*(D), Nikolaos Solomakos and Alexander Govaris
}

check for

updates

Citation: Vlachou, M.; Pexara, A.;

Solomakos, N.; Govaris, A.

Ochratoxin A in Slaughtered Pigs

and Pork Products. Toxins 2022, 14,

67. https://doi.org/10.3390/

toxins 14020067

Received: 22 November 2021

Accepted: 18 January 2022

Published: 19 January 2022

Publisher's Note: MDPI stays neutral with regard to jurisdictional claims in published maps and institutional affiliations.

Copyright: (C) 2022 by the authors. Licensee MDPI, Basel, Switzerland. This article is an open access article distributed under the terms and conditions of the Creative Commons Attribution (CC BY) license (https:// creativecommons.org/licenses/by/ $4.0 /)$.

\begin{abstract}
Laboratory of Hygiene of Foods of Animal Origin, Faculty of Veterinary Science, University of Thessaly, 43100 Karditsa, Greece; vlachoumikvet@uth.gr (M.V.); nsolom@vet.uth.gr (N.S.); agovaris@vet.uth.gr (A.G.) * Correspondence: apexara@vet.uth.gr; Tel.: +30-24410-66023
\end{abstract}

\begin{abstract}
Ochratoxin A (OTA) is a mycotoxin that is produced after the growth of several Aspergillus and Penicillium spp. in feeds or foods. OTA has been proved to possess nephrotoxic, hepatotoxic, teratogenic, neurotoxic, genotoxic, carcinogenic and immunotoxic effects in animals and humans. OTA has been classified as possibly carcinogenic to humans (Group 2B) by the IARC in 2016. OTA can be mainly found in animals as a result of indirect transmission from naturally contaminated feed. OTA found in feed can also contaminate pigs and produced pork products. Additionally, the presence of OTA in pork meat products could be derived from the direct growth of OTA-producing fungi or the addition of contaminated materials such as contaminated spices. Studies accomplished in various countries have revealed that pork meat and pork meat products are important sources of chronic dietary exposure to OTA in humans. Various levels of OTA have been found in pork meat from slaughtered pigs in many countries, while OTA levels were particularly high in the blood serum and kidneys of pigs. Pork products made from pig blood or organs such as the kidney or liver have been often found to becontaminated with OTA. The European Union (EU) has established maximum levels (ML) for OTA in a variety of foods since 2006, but not for meat or pork products. However, the establishement of an ML for OTA in pork meat and meat by-products is necessary to protect human health.
\end{abstract}

Keywords: ochratoxin A; mycotoxins; slaughtered pigs; pork products

Key Contribution: The review summarizes the state-of-the-art on OTA and focuses on the occurrence of OTA in slaughtered pigs and pork products in many countries worldwide.

\section{Introduction}

Ochratoxin A (OTA) is a mycotoxin that is produced by several fungal species of the genera Aspergillus and Penicillium in a wide variety of agricultural commodities during the field period or storage worldwide. OTA was found to possess a carcinogenic effect in animals and poultry, in addition to its nephrotoxic, hepatotoxic, teratogenic, neurotoxic, genotoxic and immunotoxic effects in animals [1-6]. OTA has been also classified as possibly carcinogenic to humans (group 2B) by the International Agency for Research on Cancer [7]. Thus, the European Commission (EC) has established maximum levels (ML) for OTA in these commodities [8].

OTA found in consumed feedstuffs [9] can adversely affect animal health and decrease the production (e.g., milk) of animals [10]. The same mycotoxin could also increase susceptibility to secondary bacterial infections in growing pigs, and immunosuppression is the first expressed toxic effect of OTA [11]. Ruminants are less sensitive to OTA intoxication as compared to monogastric animals. In ruminants, microflora in rumen can degrade OTA to the virtually non-toxic ochratoxin $\alpha(\mathrm{OT} \alpha)$ [12]. Moreover, the exposure of foodproducing animals to OTA via feed consumption can result in undesirable OTA residues in animal-derived food products ("carry-over effect" in meat, eggs or milk), contributing to the human intake of OTA via indirect transmission [13]. 
Pigs are the most susceptible animals to OTA exposure as compared to other productive animals $[14,15]$. High OTA occurrence has been recorded in feed ingredients and finished swine feeds in various countries [16-19], highlighting the pig exposure to the toxin. OTA can accumulate in several pig tissues, with the highest concentrations found in blood, followed by the kidneys and liver, whereas lower concentrations have been found in muscles and fat [20-23].

The contamination of pork meat/edible offal with OTA is mainly derived from the consumption of OTA-contaminated feed by the pigs [24,25]. Additionally, the presence of OTA in pork meat products (ham muscle, cured meats, salami or dry-cured ham) could be derived from the direct growth of OTA-producing fungi, such as Penicillium nordicum and Penicillium verrucosum [26-30], or from the addition of OTA-contaminated materials such as contaminated spices [31,32].

Pork meat and meat products are amongst the important sources of chronic dietary exposure to OTA in humans [14]. Nevertheless, the EU has not established maximum OTA levels in pork meat and pork-derived products. Some European countries have adopted regulations or guidelines on OTA concentrations in meat and/or meat products, such as Denmark, Estonia, Romania, Slovakia and Italy [33]. No binding limits on OTA in meat and meat products have been set in the USA, Australia, Canada and Asia $[34,35]$.

Several studies have been conducted worldwide on the occurrence of OTA in pork meat and pork-derived products. This review summarizes the state-of-the-art on OTA and focuses on the occurrence of OTA in slaughtered pigs and pork products.

\section{Production of OTA}

\subsection{General Factors}

OTA is mainly produced by Aspergillus and Penicillium fungi species in a wide variety of agricultural commodities, livestock products and processed food [36]. The majority of OTA-producing Aspergillus species belong to Circumdati section (A. ochraceus group, A. steynii, A. westerdijkiae) and Nigri section (A. carbonarius and A. niger) [37,38].

Apart from the main OTA toxigenic species $A$. ochraceus and A. westerdijkiae, several other Aspergillus species have been linked to OTA production, such as A. sclerotiorum, A. sulphureus, A. albertensis, A. auricomus, A. wentii, A. fumigates, A. versicolor, A. cretensis, A. flocculosus, A. pseudoelegans, A. roseoglobulosus, A. sulphurous [39], A. alliaceus [40], A. welwitschiae (formerly A. awamori) [41], A. affinis [42], A. steynii [43], A. lacticoffeatus, A. sclerotioniger [44] and A. carbonarius [45].

The OTA toxigenic Penicillium genus is classified in groups of $P$. verrucosum and P. nordicum [46] or P. thymicola [47]. Penicillia species of P. chrysogenum, P. glycyrrhizacola, P. polonicum [48], P. brevicompactum, P. crustosum, P. olsonii, P. oxalicum [49], P. nalgiovense, P. solitum, P. salamii [50] and P. commune [51] have been reported to produce OTA.

Important factors of fungal OTA production are considered to be temperature, water activity $\left(\mathrm{a}_{\mathrm{w}}\right)$ and growth medium composition. Aspergillus species predominate in warm climate regions, while Penicillium isolates are frequently found in cold climate regions [39]. A. ochraceus is commonly found in hot-tropical and semitropical climates with temperatures ranging between 12 to $37^{\circ} \mathrm{C}$ and an $\mathrm{a}_{\mathrm{w}}$ of growth substrates up to 0.77 [52,53]. The optimum temperature of OTA production by A. ochraceus is in the range of 25 and $30^{\circ} \mathrm{C}$, and the optimum $\mathrm{a}_{\mathrm{w}}$ is 0.98 [39]. In tropical regions, toxigenic OTA A. westerdijkiae strains are frequently found [43]. In Europe and Canada, P. verrucosum is mostly associated with OTA production in cereals, with optimum growth temperatures of 4 to $31^{\circ} \mathrm{C}$ and an optimum $\mathrm{a}_{\mathrm{W}}$ up to $0.8[54,55]$. P. viridicatum can produce OTA at wider ranges of temperatures from 4 to $30{ }^{\circ} \mathrm{C}$ [56]. P. nordicum can grow on substrates with high protein and salt (5\% $\mathrm{NaCl}$ ) content [57], with the maximum growth observed at $20^{\circ} \mathrm{C}$, while the highest OTA production was found at $25^{\circ} \mathrm{C}$ [24].

The growth of Aspergillus and Penicillium fungi species in feedstuffs is a significant issue for an OTA-safe feed chain supply. OTA-contaminated cereal and cereal by-products, which are important ingredients in pig feeds, are fueling concerns over the contamination 
with OTA of produced pork meat $[9,58]$. Several studies have indicated the contamination of pigs feeds with OTA [16-18]. The EC has established guidance values for OTA concerning complementary and complete feeding stuff, recommending a maximum concentration of $50 \mu \mathrm{g} / \mathrm{kg}$ for pigs [59,60]. In Brasil, Rosa et al. [19] reported that corn samples (44\%) were contaminated with $42-224 \mu \mathrm{g} / \mathrm{kg}$ of OTA, while swine feed (31\%) was contaminated with $36-120 \mu \mathrm{g} / \mathrm{kg}$ of OTA, respectively. In Costa Rica, 19 out of 57 feed samples were found to contain more than $50 \mathrm{mg} / \mathrm{kg}$ of OTA in pigs and sows [12]. In Italy, Pozzo et al. [17] found swine feed samples contaminated with OTA at $0.22-38.4 \mu \mathrm{g} / \mathrm{kg}$ levels. In the Czech Republic, Zachariasova et al. [61] found 26 samples of pig feeds contaminated with a mean OTA concentration of $3 \mu \mathrm{g} / \mathrm{kg}$, with only one sample exceeding the EU recommended OTA value of $50 \mu \mathrm{g} / \mathrm{kg}$. In China, Li et al. [18] found that $3 \%$ of the examined complete swine feeds exceeded Chinese regulatory limits for feedstuffs, set at $100 \mu \mathrm{g} / \mathrm{kg}$ for OTA.

\subsection{Production of OTA in Meat and Meat Products}

The most important Aspergillus and Penicillium OTA-producing species in meat and meat products are presented in Table 1. OTA toxigenic Aspergillus and Penicillium genera can also grow on the surface of dry cured-meat products due to their tolerance to low $\mathrm{pH}$ and high salt concentration [31,57]. The formation of OTA in the outer case or inner part of dry-cured meat products by Aspergillus or Penicillium was also examined [62,63]. The OTA toxigenic $P$. nordicum and $P$. verrucosum have been isolated in dry meat products in several European countries [64-69]. P. nordicum is a psychrotrophic fungi and widely distributed contaminant in various meat products [70-74]. It is considered an important OTA producer in dry-cured ham and dry-cured fermented sausage [24,28,70,75-78]. The ability of $P$. nalgiovense, $P$. chrysogenum, P. olsonii, P. solitum and P. salamii to produce OTA in dry meat products has been reported in previous studies [50,79].

Aspergillus spp. are less common OTA toxigenic contaminants than Penicillium spp. in dry-cured meats, since these products are processed at a low temperature and Aspergillus spp. usually requires higher temperatures than Penicillium spp. [80]. The occurrence of A. westerdijkiae has already been described in various meat products in many countries worldwide [30,81-83], and its growth was associated with the presence of the OTA toxin in dry-cured meat products [84-86]. A. ochraceus was detected in OTA-contaminated sausages [75] or dry cured ham $[27,76]$.

In recent studies, the relationship between OTA production and the expression of the genes potentially involved in OTA biosynthesis have been examined in meat products [87-89].

Table 1. OTA producing Aspergillus spp. and Penicillium spp. in meat and meat products.

\begin{tabular}{ccc}
\hline Species & Foodstuffs & References \\
\hline \multirow{3}{*}{ A. ochraceus } & Aspergillus spp. & \\
& Processed meat & {$[90]$} \\
& Meat & {$[91]$} \\
& Dry-cured ham & {$[27]$} \\
A. niger & Sausages, speck & {$[75]$} \\
A. westerdijkiae & Dry-cured meat products & {$[57]$} \\
P. verrucosum & Dry-cured meat products & {$[57]$} \\
& Meat products & {$[30,70,84,85,92,93]$} \\
& Penicillium spp. & {$[94]$} \\
P. nalgiovense & Sausage casings & {$[57]$} \\
& Sausages & {$[95]$} \\
& Dry-cured meat products & {$[50]$} \\
\hline
\end{tabular}


Table 1. Cont.

\begin{tabular}{|c|c|c|}
\hline Species & Foodstuffs & References \\
\hline \multirow{12}{*}{ P. nordicum } & Meat products & {$[46,96]$} \\
\hline & Dry-cured ham & {$[64,65,95]$} \\
\hline & Meat & [97] \\
\hline & Cured meat & [98] \\
\hline & Fermented meat & [99] \\
\hline & Fermented sausage, liver pâté & [100] \\
\hline & Dry-cured meat & {$[70,71,84]$} \\
\hline & Sausage casings & [94] \\
\hline & Sausages & {$[75,101]$} \\
\hline & $\begin{array}{l}\text { Meat product (Italian } \\
\text { culatello) }\end{array}$ & [93] \\
\hline & Salami & {$[28,67]$} \\
\hline & Speck & {$[76]$} \\
\hline $\begin{array}{l}\text { P. salami, } \text { P. solitum, } \\
\text { P. chrysogenum, P. olsonii }\end{array}$ & Dry-cured meat (salami) & {$[50]$} \\
\hline
\end{tabular}

\section{Physicochemical Properties of OTA}

The chemical name of OTA is L-phenylalanine-N-[(5-chloro-3,4-dihydro-8-hydroxy-3methyl-1-oxo-1H-2-benzopyrane-7-yl)carbonyl]-(R)-isocoumarin. OTA consists of an isocumarin nucleus bonded to an L-phenylalanine unit by an amide bond [3].

After OTA ingestion in human or animals, several OTA derivatives are transformed. Certain OTA derivatives are hydroxylated, while others lack phenylalanine moiety or are conjugated (e.g., with glutathione, glucuronic acid, sulfate or pentose). Among the OTA metabolites are the dechloro analog ochratoxin B (OTB), the dechloro analog ochratoxin $\beta$ $(\mathrm{OT} \beta)$, the ethyl ester ochratoxin C (OTC) and the isocoumaric derivative OT $\alpha$ [32]. The OTA metabolites usually possess low or no toxicity $[102,103]$.

OTA is stable to heat treatments and low $\mathrm{pH}$ conditions. Typical heat treatments of foods such as boiling, baking, frying and roasting do not cause any important decrease in OTA levels $[104,105]$. Pleadin et al. [106] found that the 30 min cooking $\left(100{ }^{\circ} \mathrm{C}\right)$ and frying $\left(170{ }^{\circ} \mathrm{C}\right)$ of contaminated sausages proved insufficient to decrease OTA levels.

Innovative food-processing methods such as irradiation, cold plasma (CP) and highpressure processing (HPP) may be an effective means of OTA decrease in foods by controlling the growth of OTA-producing fungi $[107,108]$. Despite the promising results of these new technologies in the treatment of OTA-contaminated food, there is a great concern regarding the toxicity of the OTA degradation compounds and consequent implications on human and animal health [109]. The majority of innovative food-processing studies have been conducted in food of plant origin and not in foods of animal origin.

\section{Toxicity of OTA}

Several studies have indicated that OTA has nephrotoxic, hepatotoxic, teratogenic, neurotoxic, genotoxic and immunotoxic effects and can cause tumors in organs and tissues such as the kidneys, liver, intestine, ureters, lung, oculi and muscles of animals and humans $[5,6,35,60,110]$. The consumption of OTA-contaminated feed can adversely affect animals' health and has been associated with several animal diseases, including porcine nephropathy, avian ochratoxicosis and carcinogenicity in rodents and poultry $[5,6,60,111]$.

In humans, dietary exposure to OTA represents a serious health issue, including endemic nephropathies and urinary tract tumors [112]. OTA has been classified as possibly carcinogenic to humans (Group 2B) by the IARC due to evidence of OTA-mediated carcinogenicity in laboratory animals [7].

In many animal species and in humans, the primary target organ of OTA is the kidney [14]. The nephrotoxic effect of the toxin has been demonstrated by various studies performed on laboratory animals $[2,35]$. Severe nephrotoxicity has been detected in rats [113], with renal damages characterized by disorganization of the tubules, apoptosis, polyploidy in the proximal convo- 
luted tubule (PCT) and an increase in the nucleus-cytoplasm ratio of their kidneys [114-117]. Furthermore, tubular nephrosis and hemorrhage were detected in rat kidneys [118]. Similarly, hemorrhage, tubular necrosis, mesangial hypercellularity and glomerulosclerosis were detected in the kidneys of rodents [119-122].

Among food-producing animals, pigs are the most susceptible animals to OTA exposure [10,11]. In pigs, OTA usually causes kidney disease by damaging proximal tubules [51]. It was initially described as spontaneous nephropathy in Bulgaria and was observed frequently during the carcass inspection of pigs with nephropathy problems. These pathomorphological changes in kidneys resemble those in mycotoxic porcine nephropathy observed in South Africa, both of which have a multi-mycotoxic etiology and are differentiated from mycotoxic porcine nephropathy described in Denmark [123].

In humans, even though the epidemiological evidence was inadequate, OTA exposure was associated with Balkan Endemic Nephropathy (BEN), Chronic Interstitial Nephropathy (CIN) and other kidney diseases [124,125]. BEN, firstly recognized in the 1950s [126], was characterized by progressive kidney and urinary tract tumors in people living in the Balkans, mainly in Bulgaria, Romania and former Yugoslavia $[127,128]$. However, later studies have associated epigenetic changes as a possible cause of the disease $[129,130]$. The identification of the causative factors of BEN seems to be difficult. New scientific findings are constantly emerging, and toxic compounds produced by other fungi such as P. polonicum, P. aurantiogriseum and P. commune have been also associated with the etiology of BEN [131]. It has also been suggested that the disease is rather associated with exposure to other mycotoxins than OTA, and the chronic dietary intake of aristolochic acid has been stated to be mainly responsible for BEN [132,133].

In humans, two other forms of CIN nephropathy observed in Tunisia were associated with OTA [134]. However, recent studies revealed that CIN nephropathies found in Tunisia have no connection with OTA [14].

Apart from the kidneys, the liver is one of the major target organs of OTA biotransformation [135]. Significant lesions have also been observed in rat livers [135-137]. In mice, approximately $33 \%$ of OTA is eliminated through the hepatobiliary route of excretion, and the enterohepatic recirculation of the toxin in mice and rats is mainly responsible for the liver damages in these species [138]. Furthermore, OTA affects reproduction systems and fertility in animals [113].

\section{Regulations on OTA in Pork Meat and Meat Products}

There are remarkable differences in legal regulations of the presence of OTA in feeds or foods among various countries. In the USA, no limits on OTA in foods or feed have been set [34]. The US Food and Drug Administration (FDA), acting under the Federal Food, Drug and Cosmetic Act (FFDCA), requires the implementation of food safety plans in food industries and for good agricultural and manufacturing practices to be applied. In addition, certain countries such as Australia and Canada have adopted a similar approach on OTA [35].

Legislation differences exist in various countries in Asia. In China, Indonesia, Korea, Malaysia and recently in Singapore, legislative limits have been set for OTA in foods and feed, but not in meat and meat products [139]. In Japan, OTA is not regulated by defined maximum levels in foods and, in accordance with the USA, food safety guidelines have also been applied [35].

The EU, based on the scientific opinion of the scientific panel on contaminants in the food chain of the EFSA, established maximum limits for OTA in a variety of foods in Commission Regulation (EC) No. 1881/2006 [8], which is active today, although it has been repeatedly changed. Furthermore, a maximum level for OTA has been defined for some spices used in the production of meat products [8,140]; for example, $15 \mathrm{ng} / \mathrm{g}$ for white and black pepper; $20 \mathrm{ng} / \mathrm{g}$ for dired chillies, chilli powder and paprika; and $15 \mathrm{ng} / \mathrm{g}$ for mixtures containing one or more of the aforementioned spices.

However, in pork meat and meat products and other foods of animal origin, OTA limits have been not set yet. Instead, in many EU member countries, to protect consumers from OTAcontaminated pork meat, edible offal and derived products have been subject to regulations 
or guidelines to limit exposure, such as in Denmark $(10 \mu \mathrm{g} / \mathrm{kg}$ in pig kidney, $25 \mu \mathrm{g} / \mathrm{mL}$ in pig blood), Estonia (10 $\mu \mathrm{g} / \mathrm{kg}$ in pig liver), Romania ( $5 \mu \mathrm{g} / \mathrm{kg}$ in pig kidney, liver and meat) and Slovakia (5 $\mathrm{gg} / \mathrm{kg}$ in meat), Italy ( $1 \mu \mathrm{g} / \mathrm{kg}$ in pork meat and derived products) [33]. The differences in OTA limits necessitate a harmonized approach to legally regulating OTA in pork meat, edible offal and meat products in EU countries.

\section{Methods for the Detection and Determination of OTA}

Several analytical methods have been used for the detection and measurement of OTA in feeds and foods $[35,112,141,142]$. However, the most common analytical methods are highperformance liquid chromatography (HPLC), enzyme-linked immunosorbent assay (ELISA) and thin-layer chromatography (TLC) [35]. Meat is a complex compound matrix and poses difficulties in OTA analysis due to the strong bonds between proteins and OTA and the presence of fat, which may be also co-extracted [143]. Therefore, for OTA analysis in protein-rich foods such as meat, acidic solvents are used to break the protein bonds [144]. Additionally, the presence of the OTA at trace levels in meat demands sensitive and accurate analytical methods for OTA detection [23].

HPLC with fluorescence detector (HPLC-FLD) has shown good analytical performance for OTA determination in pork tissues and organs, as the limits of detection (LOD) and limits of quantification (LOQ) values were found to be quite low. In pork meat, low levels of LOD at $0.01 \mu \mathrm{g} / \mathrm{kg}$ [145] and LOQ at $0.03 \mu \mathrm{g} / \mathrm{kg}$ [146] were reported by using HPLC-FLD analysis. Similarly, a low LOD at 0.0125 and LOQ at $0.0250 \mu \mathrm{g} / \mathrm{kg}$ were found in pork meat by using HPLC-FLD analysis [15]. Similar HPLC-FLD sensitivity was found in pork kidney and liver with the LOD and LOQ levels at $0.001 \mu \mathrm{g} / \mathrm{kg}$ and $0.002 \mu \mathrm{g} / \mathrm{kg}$, respectively [147]. HPLC-FLD based on an immunoaffinity clean-up step, with a range of applicability of 0.4 to $12 \mu \mathrm{g} / \mathrm{kg}$ of OTA, was used for the quantification of OTA in kidney, liver, lung and pork-derived products [148]. The HPLC-FLD method has also been used for the determination of OTA in pig tissues [22,149] and in meat products [32,150].

The ELISA method is also an effective quantitative method for OTA screening in pork meat products $[29,31,57,151]$. An ELISA analysis for OTA presence was used in dry-cured meat products, cooked sausages and pork raw materials such as blood, brain, liver, kidney, adipose tissue, lungs and spleen [21,31,152].

The use of enzymatic digestion (ED) extraction significantly reduces matrix interference with the OTA in meat, leading to more reliable results of the OTA analytical methods $[147,153]$. For example, ED with the pancreatin method coupled to HPLC-FLD has been successfully used for the rapid analysis of OTA in pork meat and pork products $[147,153,154]$. Furthermore, ED use with HPLC for OTA quantification in pig muscle resulted in LOD and LOQ levels of $0.21 \mu \mathrm{g} / \mathrm{kg}$ and $0.70 \mu \mathrm{g} / \mathrm{kg}$, respectively [155]. Several analytical procedures based on LC-MS/MS have been developed for the detection of OTA in pork meat products $[13,156,157]$. Furthermore, the LC-MS/MS analysis of OTA in traditional dry-fermented homemade sausages gave low LOD and LOQ values of $0.44 \mu \mathrm{g} / \mathrm{kg}$ and $1.44 \mu \mathrm{g} / \mathrm{kg}$, respectively, indicating a high prevalence of OTA in these meat products [56]. It has been also proved that a sensitive liquid chromatography/electrospray ionization tandem mass spectrometry (LC/ESI-MS/MS) method could be used for the quantitative monitoring of OTA in pig kidney samples [158] and other pork tissues such as liver and muscle [156,157]. A new developed immunoaffinity column clean-up step (IAC)-LC-ESI-MS/MS was also used for OTA examination in pork meat samples [144].

Ultra-performance liquid chromatography (UPLC) has been also used for OTA detection in meat $[159,160]$, with a higher OTA analytical sensitivity as compared to HPLC [161]. Brera et al. [158], comparing HPLC-FLD and ultra-performance liquid chromatography tandem mass spectrometry (UPLC-MS/MS), concluded that both methods are suitable for the detection of OTA in ham.

In order to detect potentially ochratoxinogenc fungi and quantify the genes involved in the biosynthesis of OTA production, tge quantitative real time PCR (qPCR) method was also used [27]. 


\section{Occurrence of OTA in Slaughtered Pigs}

In pigs, the highest concentrations of OTA are usually found in the blood, followed by the kidneys, liver, muscles and fat [16-19]. This OTA distribution trend in pig organs was also verified in pigs fed with OTA contaminated feed due to the "carry-over" effect (Table 2). The OTA levels in pig tissues were dependent on the OTA levels administrated in feed as well as the duration of feeding with OTA-contaminated feed [122,162]. Pigs fed with naturally contaminated feed showed higher OTA serum/plasma levels compared to studies in which pigs were fed OTA-contaminated feed [163].

Accomplished data on the occurrence of OTA in edible pig tissues from published studies conducted in various countries worldwide are summarized in Table 3. According to several studies of slaughtered pigs accomplished in various countries, the occurrence of OTA-positive samples was high in pig tissues, and particularly in blood serum and kidneys. For example, $98 \%$ and $94 \%$ of porcine serum samples tested by HPLC-FD in Romania in the studies of Curtui et al. [164] and Curtui and Gareis [165], respectively, were found to be OTA-positive. Curtui and Gareis [165] reported that the levels of OTA were in the range of $0.1-13.4 \mu \mathrm{g} / \mathrm{L}$ in porcine serum samples. In Canada, pig serum analysis revealed that all the positive samples had concentrations of OTA between 5.4 to $20 \mu \mathrm{g} / \mathrm{L}$ in the years 1988-1990 [166]. A lower incidence of OTA $(31.1 \%)$ was found in pig serum in Serbia with OTA levels ranging between 0.22 and $220.8 \mu \mathrm{g} / \mathrm{L}$ [167].

The presence of OTA in kidneys is considered to be a good indicator of overall exposure of pigs to the toxin [149]. Several surveys conducted in various countries revealed that OTA occurrence in kidney samples of healthy pigs using HPLC-FD analysis was in the range from $8 \%$ [168] to $14.74 \%$ [149]. However, according to a study by Hou et al. [159], in kidney samples of healthy pigs using ultra-HPLC/MS/MS analysis, the occurrence was $87.5 \%$. Various OTA levels in pig kidneys have been reported. In Italy, OTA levels in kidneys were in the range of $0.17-0.91 \mu \mathrm{g} / \mathrm{kg}$ [147] and 0.07-3.23 $\mu \mathrm{g} / \mathrm{kg}$ [153] for pigs and wild boars, respectively. In the Czech Rebublic, Skarkova et al. [168] reported OTA levels of $0.15-0.46 \mu \mathrm{g} / \mathrm{kg}$ in pig kidneys. In China, the OTA concentrations ranged between 0.03 to $0.323 \mu \mathrm{g} / \mathrm{kg}$ in pig kidneys [160]. However, Polovinski-Horvatovic et al. [148] found OTA levels in examined pig kidneys as high as $3.97 \mu \mathrm{g} / \mathrm{kg}$ in Serbia. In a recent study in Belgium, 37.3\% of kidney samples were OTA-contaminated at the mean level of $0.22 \pm 0.25 \mu \mathrm{g} / \mathrm{kg}$ (up to $1.91 \mu \mathrm{g} / \mathrm{kg}$ ) [169].

Various levels of OTA have been found to be present in the livers or muscles of slaughtered pigs. In the livers of pigs, OTA levels as high as $100 \%$ and $33 \%$ were found by using HPLC-FD or LC-MS/MS, respectively [147,153]. OTA levels in pig liver of $1.46 \mu \mathrm{g} / \mathrm{kg}$ [156] and $0.10-3.65 \mu \mathrm{g} / \mathrm{kg}$ [23] were reported in China and France, respectively. In Italy, Giacomo et al. [146] reported OTA concentrations in pork liver samples with a range of 0.07-0.59 $\mu \mathrm{g} / \mathrm{kg}$ and a mean value of $0.35 \mu \mathrm{g} / \mathrm{kg}$. Similarly, in Italy, Luci et al. [152] found that OTA ranged from 0.02 to $1.93 \mu \mathrm{g} / \mathrm{kg}$ in livers of wild boars. The levels of OTA in muscles of slaughtered pigs were $8 \%$ in the Czech Rebublic [168] and 33.33\% [56] in China. High percentages of OTA presence in muscles of slaughtered pigs in France were found with a range of $76 \%$ to $100 \%$ [23]. Luci et al. [152] examined 48 muscle samples of slaughtered pigs in Italy, and all of them were positive for OTA presence. Pig muscles were found to be contaminated with OTA with a range of 0.15 to $0.20 \mu \mathrm{g} / \mathrm{kg}$ in the Czech Republic [168], 0.09-0.20 $\mu \mathrm{g} / \mathrm{kg}$ in Italy [146] and $0.03-0.23 \mu \mathrm{g} / \mathrm{kg}$ in Canada [170]. In a recent study conducted in Italy, Meucci et al. [15] found that the maximum OTA concentrations in pig muscles reared in an indoor system were $0.055 \mu \mathrm{g} / \mathrm{kg}$ and $0.078 \mu \mathrm{g} / \mathrm{kg}$ in indoor and outdoor systems, respectively. Analysis by LC-MS/MS showed higher OTA levels in muscles of $1.25 \mu \mathrm{g} / \mathrm{kg}$ in China [156] and $0.88 \mu \mathrm{g} / \mathrm{kg}$ in Italy [171]. Analysis by SIDA-UHPLC-MS/MS showed also high levels of OTA (maximum $1.15 \mu \mathrm{g} / \mathrm{kg}$ ) in the muscles of French pigs from organic farming production systems [23]. The OTA levels in the fat of slaughtered pigs in Italy were found to be low, with values ranging $0.079 \pm 0.018 \mu \mathrm{g} / \mathrm{kg}$ and $0.085 \pm 0.025 \mu \mathrm{g} / \mathrm{kg}$ for indoor and outdoor systems, respectively. 
Table 2. Distribution of OTA in tissues of pigs fed with OTA-contaminated feed.

\begin{tabular}{|c|c|c|c|c|c|}
\hline \multirow{2}{*}{ OTA Treatment } & \multicolumn{2}{|c|}{ Sample } & \multirow{2}{*}{ OTA Content $(\mu \mathrm{g} / \mathrm{kg}-\mu \mathrm{g} / \mathrm{L})$} & \multirow[b]{2}{*}{ Method $^{2}$} & \multirow{2}{*}{ Reference } \\
\hline & Type & Number & & & \\
\hline $\begin{array}{c}1 \text { male, } 1 \text { female control, } \\
1 \text { male, } 1 \text { female OTA-treated } \\
(0.8 \mu \mathrm{g} / \mathrm{kg} \text { feed }) / 6 \text { months }\end{array}$ & Kidneys & $\begin{array}{l}2 \text { control } \\
2 \text { treated }\end{array}$ & $\begin{array}{l}12.1 \text { and } 9.6 \text { (control) } \\
98.3 \text { and } 103.8 \text { (treated) }\end{array}$ & HPLC-FD & [172] \\
\hline $\begin{array}{l}\text { Control/OTA-treated } \\
(25 \mu \mathrm{g} / \mathrm{kg} \text { feed }) / 119 \text { days }\end{array}$ & $\begin{array}{c}\text { Kidneys } \\
\text { Liver } \\
\text { Meat (Semimembranosus muscle) }\end{array}$ & $\begin{array}{l}32 \text { control } \\
32 \text { treated }\end{array}$ & $\begin{array}{c}10.50 \text { (control) } \\
69 \text { (treated) } \\
3.50 \text { (control) } \\
52.00 \text { (treated) } \\
0.88 \text { (control) } \\
6.10 \text { (treated) }\end{array}$ & HPLC-FD & [173] \\
\hline OTA treated: $2.5 \mathrm{mg} / \mathrm{kg}$ feed & $\begin{array}{c}\text { Kidneys } \\
\text { Liver } \\
\text { Meat (heart/muscle) }\end{array}$ & 5 treated & $\begin{array}{l}\text { Mean: } 29.15 \\
\text { Mean: } 20.1 \\
\text { Mean: } 12.6\end{array}$ & TLC and spectrophotometry & [174] \\
\hline \multirow{4}{*}{$\begin{array}{l}\text { T0: control group, OTA treated } \\
\text { groups (T1-T3): } \\
50,100,200 \mu \mathrm{g} / \mathrm{kg} \text { feed } / 2 \text { weeks }\end{array}$} & $\begin{array}{l}\text { Blood } \\
\text { Kidneys }\end{array}$ & & $\begin{array}{c}\text { T0: }<0.02-0.26 \text {, Mean: } 0.19 \\
\text { T1: } 5.24-7.51 \text {, Mean: } 6.35 \\
\text { T2: 7.41-16.5, Mean:11.4 } \\
\text { T3: } 17.3-34.5 \text {, Mean: } 24.6 \\
\text { T0: }<0.04-0.32 \text {, Mean: } 0.13 \\
\text { T1: } 2.75-4.37 \text {, Mean: } 3.74 \\
\text { T2: } 4.56-5.72 \text {, Mean: } 5.24 \\
\text { T3: } 7.33-11.8 \text {, Mean:10 }\end{array}$ & $\begin{array}{c}\text { HPLC-FD } \\
\text { LOD: } 0.02 \text {, LOQ: } 0.05\end{array}$ & \multirow{4}{*}{ [175] } \\
\hline & Liver & 24 (total) & $\begin{array}{c}\text { T0: }<0.04-0.14 \text {, Mean: } 0.06 \\
\text { T1: } 1.26-1.82 \text {, Mean: } 1.60 \\
\text { T2: } 1.91-2.56 \text {, Mean: } 2.35 \\
\text { T3: 3.16-6.98, Mean: } 4.29 \\
\text { T0: ND }{ }^{1}\end{array}$ & LOD: 0.04, LOQ: 0.10 & \\
\hline & Meat & & $\begin{array}{l}\text { T1: } 0.60-0.89 \text {, Mean: } 0.74 \\
\text { T2: } 1.08-1.45 \text {, Mean: } 1.27 \\
\text { T3: } 1.67-3.40 \text {, Mean: } 2.23\end{array}$ & LOD: 0.04, LOQ: 0.10 & \\
\hline & Fat & & $\begin{array}{c}\text { T0: ND } \\
\text { T1: } 0.57-0.79 \text {, Mean: } 0.68 \\
\text { T2: } 0.86-1.26 \text {, Mean: } 1.04 \\
\text { T3: } 1.33-2.58 \text {, Mean: } 1.71\end{array}$ & LOD: 0.02, LOQ: 0.05 & \\
\hline
\end{tabular}


Table 2. Cont.

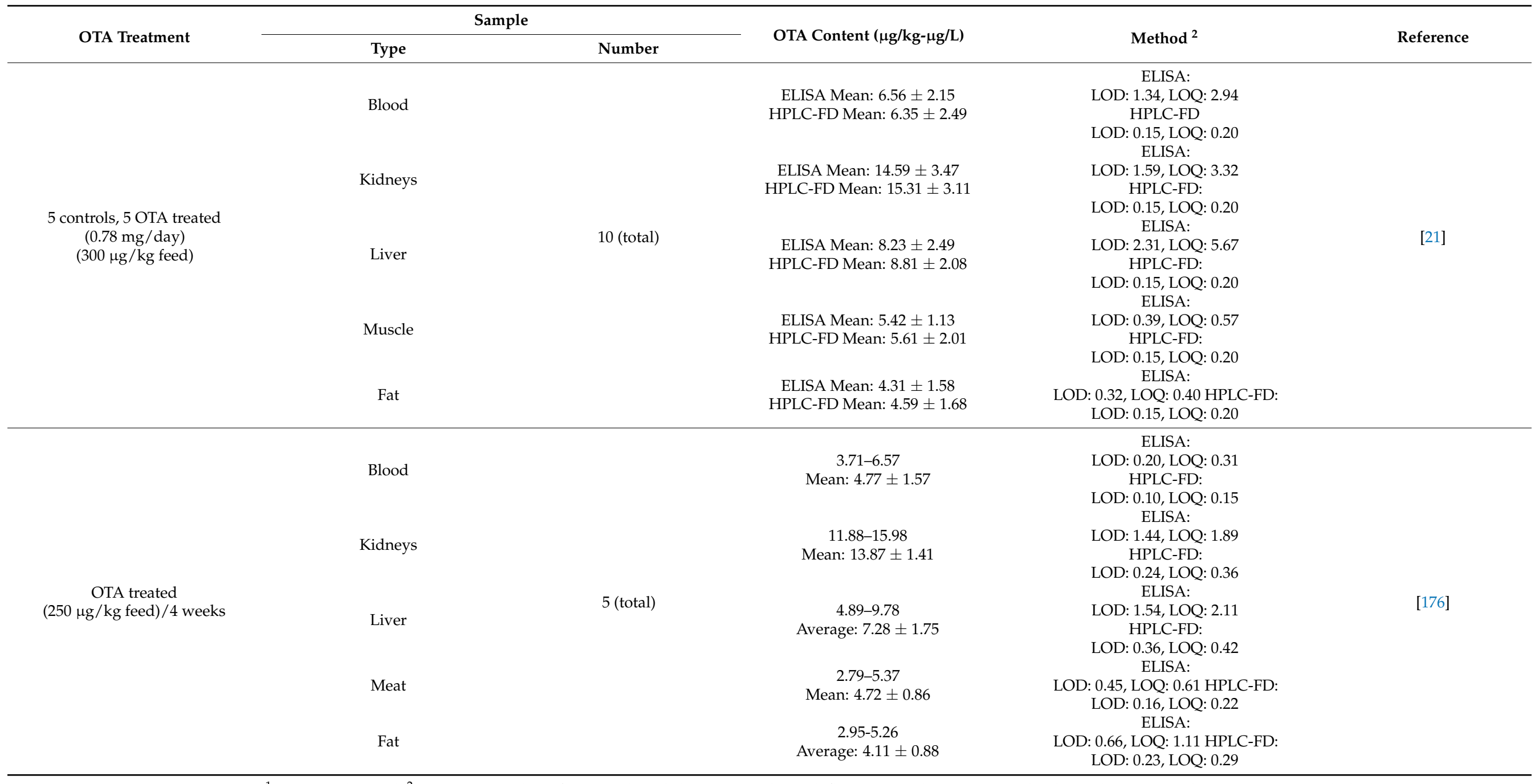

${ }^{1}$ ND: Not detected. ${ }^{2}$ HPLC-FD: High-performance liquid chromatography with fluorescence detector; TLC: Thin layer chromatography; ELISA: Enzyme-linked immunosorbent assay; LOD: Limit of detection ( $\mu \mathrm{g} / \mathrm{kg}-\mu \mathrm{g} / \mathrm{L})$; LOQ: Limit of quantification $(\mu \mathrm{g} / \mathrm{kg}-\mu \mathrm{g} / \mathrm{L})$. 
Table 3. Occurrence of OTA in meat and edible offal of slaughtered pigs.

\begin{tabular}{|c|c|c|c|c|c|c|c|}
\hline \multirow[b]{2}{*}{ Samples } & \multirow[b]{2}{*}{ Country } & \multirow[b]{2}{*}{ Year/Years of Study } & \multicolumn{2}{|c|}{ OTA Prevalence } & \multirow[b]{2}{*}{ Method $^{2}$} & \multirow[b]{2}{*}{ Comments } & \multirow[b]{2}{*}{ Reference } \\
\hline & & & $\begin{array}{c}\text { Positive/Number Tested } \\
\text { (\% Positive) }\end{array}$ & $\begin{array}{c}\text { Concentration } \\
(\mu \mathrm{g} / \mathrm{kg}-\mu \mathrm{g} / \mathrm{L})\end{array}$ & & & \\
\hline \multirow[t]{3}{*}{ Blood } & Canada & 1988 & $\begin{array}{c}1200 \text { Total } \\
(3.6 \% \text { of } 194) \\
(4.2 \% \text { of } 1006)\end{array}$ & $>20$ & HPLC-FD & & [166] \\
\hline & & 1989-1990 & $\begin{array}{c}16-65 \% \\
25 / 75\end{array}$ & $\begin{array}{l}\text { 5.4-19.4 } \\
\text { Mean: }\end{array}$ & & & \\
\hline & Bulgaria & 1993-1994 & $\begin{array}{l}(48-64 \% \text {, autumn }) \\
(60.88 \text { spring })\end{array}$ & $\begin{array}{c}\text { 4.8-21.94 (autumn) } \\
\text { 60.88 (spring) } \\
98 \%: 0.05-13.4\end{array}$ & HPLC & & [177] \\
\hline \multirow[t]{3}{*}{ Serum } & Romania & 1998 & 52 (Total) & $\begin{array}{l}92 \%: \geq 0.1 \\
\text { Max: } 13.4 \\
\text { Mean: } 2.43\end{array}$ & HPLC-FD & LOD: 0.1 & [164] \\
\hline & Romania & $\mathrm{NR}^{1}$ & $49 / 52(94 \%)$ & $0.1-13.4$ & HPLC-FD & LOD: 0.1 & [165] \\
\hline & Serbia & 2006-2007 & $28 / 90(31 \%)$ & $\begin{array}{c}0.22-220.8 \\
\text { Mean: } 3.70 \pm 23.59\end{array}$ & HPLC-FD & LOD: 0.1 & [167] \\
\hline \multirow{12}{*}{ Kidneys } & Bulgaria & 1994 & $\begin{array}{c}80-100 \% \\
\text { (nephropathic kidneys) }\end{array}$ & Mean: 1.5-7.17 & & $\begin{array}{l}\text { Samples from porcine } \\
\text { nephropathy } \\
\text { affected farms }\end{array}$ & [178] \\
\hline & France & 1997 & $\begin{array}{l}3 / 300(1 \%) \\
6 / 100(6 \%)\end{array}$ & $\begin{array}{l}\text { 1\%: } 0.40-1.40 \\
6 \%: 0.16-0.48\end{array}$ & HPLC-FD & $\begin{array}{l}300 \text { Healthy pigs } \\
100 \text { Nephropathic pigs } \\
\text { LOD: } 0.05 \text {, LOQ: } 0.16\end{array}$ & [179] \\
\hline & France & 1998 & $238 / 710(33.5 \%)$ & $\begin{array}{c}\text { 184/710 (25.9\%): LOD-0.5 } \\
54 / 710(7.6 \%): 0.5-5\end{array}$ & HPLC-FD & LOD: 0.05, LOQ: 0.16 & \\
\hline & $\begin{array}{l}\text { Germany } \\
\text { Romania }\end{array}$ & $\begin{array}{c}\text { NR } \\
1998\end{array}$ & $\begin{array}{l}26 / 58(44 \%) \\
41 / 52(79 \%)\end{array}$ & $\begin{array}{c}\text { Max: } 9.3 \\
\text { Max: 3.18, Mean: } 0.54\end{array}$ & $\begin{array}{l}\text { HPLC-FD } \\
\text { HPLC-FD }\end{array}$ & $\begin{array}{l}\text { LOD: } 0.01 \\
\text { LOD: } 0.01\end{array}$ & $\begin{array}{l}{[180]} \\
{[165]}\end{array}$ \\
\hline & Denmark & 1999 & $284 / 300(94.7 \%)$ & $\begin{array}{c}0-15 \\
\text { Mean: } 0.50, \text { Median: } 0.18\end{array}$ & HPLC-FD & LOD: 0.02, LOQ: 0.06 & [181] \\
\hline & $\begin{array}{l}\text { Italy } \\
\text { Italy }\end{array}$ & $\begin{array}{l}\text { NR } \\
\text { NR }\end{array}$ & $52 / 54(96 \%)$ & $\begin{array}{l}0.26-3.05 \\
\text { Mean. } 029 \text { Max. } 09\end{array}$ & $\begin{array}{l}\text { HPLC-FD } \\
\text { ELISA }\end{array}$ & $\begin{array}{l}\text { LOD: 0.14, LOQ: } 0.52 \\
\text { LOD: } 0.01\end{array}$ & {$[182]$} \\
\hline & $\begin{array}{l}\text { Italy } \\
\text { Italy }\end{array}$ & $\begin{array}{l}\mathrm{NR} \\
2005\end{array}$ & $\begin{array}{c}54 / 54(100 \%) \\
5 \text { (Total) }\end{array}$ & $\begin{array}{c}\text { Mean: } 0.29, \text { Max: } 0.9 \\
23.9-27.5 \\
\text { Average: } 25.6 \pm 1.56\end{array}$ & $\begin{array}{c}\text { ELISA } \\
\text { HPLC-FD }\end{array}$ & LOD: 0.10, LOQ: 0.30 & {$[184]$} \\
\hline & Serbia & $2006-2007$ & $30 / 90(33.3 \%)$ & $\begin{array}{c}0.17-52.5 \\
\text { Mean: } 1.26 \pm 5.85\end{array}$ & HPLC-FD & LOD: 0.01 & [167] \\
\hline & Czech Rebublic & 2011-2012 & $8 \%$ & $0.15-0.46$, Mean: 0.18 & HPLC-FD & LOD: 0.10, LOQ: 0.30 & [168] \\
\hline & China & 2014 & $35 / 40$ & $(0.03-0.1)$ to 0.323 & UHPLC-MS/MS & LOD: 0.03 , LOQ: 0.10 & [159] \\
\hline & Italy & NR & $5 / 5(100 \%)$ & $\begin{array}{c}0.17-0.91 \\
\text { Mean: } 0.37 \pm 0.30\end{array}$ & HPLC-FD (ED) & LOD: 0.001, LOQ: 0.002 & {$[147]$} \\
\hline & Belgium & 2012-2019 & $41 / 110(37.3 \%)$ & Mean: $0.22 \pm 0.25$ & LC-MS/MS & LOD: 0.2 & [169] \\
\hline
\end{tabular}


Table 3. Cont.

\begin{tabular}{|c|c|c|c|c|c|c|c|}
\hline \multirow[b]{2}{*}{ Samples } & \multirow[b]{2}{*}{ Country } & \multirow[b]{2}{*}{ Year/Years of Study } & \multicolumn{2}{|c|}{ OTA Prevalence } & \multirow[b]{2}{*}{ Method $^{2}$} & \multirow[b]{2}{*}{ Comments } & \multirow[b]{2}{*}{ Reference } \\
\hline & & & $\begin{array}{l}\text { Positive/Number Tested } \\
\text { (\% Positive) }\end{array}$ & $\begin{array}{l}\text { Concentration } \\
(\mu \mathrm{g} / \mathrm{kg}-\mu \mathrm{g} / \mathrm{L})\end{array}$ & & & \\
\hline \multirow[t]{2}{*}{ Kidneys of wild boars } & Italy & 2014-2015 & $\begin{array}{c}48 \text { (Total) } \\
\text { 2014:26/26 (100\%) } \\
2015: 22 / 22(100 \%)\end{array}$ & $\begin{array}{l}\text { 2014: } 0.19-3.23 \\
\text { Median: } 0.68 \\
\text { 2015: } 0.07-1.72 \\
\text { Median: } 0.34\end{array}$ & HPLC-FD (ED) & LOD: 0.001, LOQ: 0.002 & [120] \\
\hline & Serbia & 2018 & $14 / 95(14.74 \%)$ & $\begin{array}{c}\text { 0.10-3.97 } \\
\text { Average: } 1.36 \\
\text { Median: } 0.99\end{array}$ & HPLC-FD & LOQ: 0.10 & [148] \\
\hline \multirow{5}{*}{ Liver } & Romania & 1998 & $39 / 52(75 \%)$ & $\begin{array}{l}\text { Max: } 0.61 \\
\text { Mean: } 0.16\end{array}$ & HPLC-FD & LOD: 0.01 & [165] \\
\hline & Italy & 2005 & 5 (Total) & $\begin{array}{c}\text { 3.2-5.3 } \\
\text { Average: } 4.4 \pm 0.8\end{array}$ & HPLC-FD & LOD: 0.10, LOQ: 0.30 & [184] \\
\hline & Serbia & 2006-2007 & $24 / 90(26.6 \%)$ & $\begin{array}{c}0.22-14.5 \\
\text { Mean: } 0.63+1.87\end{array}$ & HPLC-FD & LOD: 0.01 & [167] \\
\hline & China & NR & $1 / 3(33.33 \%)$ & 1.46 & LC-MS/MS & LOQ: $0.25-1.0$ & [156] \\
\hline & Italy & NR & $5 / 5(100 \%)$ & $\begin{array}{c}0.07-0.59 \\
\text { Mean: } 0.35 \pm 0.20\end{array}$ & HPLC-FD (ED) & LOD: 0.001, LOQ: 0.002 & [147] \\
\hline \multirow[t]{2}{*}{ Liver of wild boars } & Italy & 2014-2015 & $\begin{array}{c}48 \text { (Total) } \\
\text { 2014: } 26 / 26(100 \%) \\
\text { 2015: } 22 / 22(100 \%)\end{array}$ & $\begin{array}{c}\text { 2014: 0.04-1.93 } \\
\text { Median: } 0.15 \\
\text { 2015: 0.02-1.31 } \\
\text { Median: } 0.23\end{array}$ & HPLC-FD (ED) & LOD: 0.001, LOQ: 0.002 & [153] \\
\hline & France & 2014 & $47 / 70(67 \%)$ & $\begin{array}{c}0.10-3.65 \\
\text { Conventional }\end{array}$ & SIDA-UHPLC-MS/MS & LOD: 0.03, LOQ: 0.10 & [23] \\
\hline Pork meat and liver & Denmark & 1993-1994 & $\begin{array}{c}64 / 76(84.2 \%) \text { (conventional) } \\
4 / 7(57.1 \%) \text { (ecological) }\end{array}$ & $\begin{array}{c}\text { Max: } 1.3 \\
\text { Mean: 0.11, Median: } 0.09 \\
\text { Ecological } \\
\text { Max: } 0.12, \text { Mean: } 0.05, \\
\text { Median: } 0.05\end{array}$ & HPLC-FD & LOD: $0.02-0.03$ & [185] \\
\hline \multirow{3}{*}{ Meat } & Germany & NR & $10 / 58(17.2 \%)$ & Max: 0.14 , Median: $<0.01$ & HPLC-FD & LOD: 0.01 & [180] \\
\hline & Romania & 1998 & $9 / 54(17 \%)$ & Max: 0.53, Mean: 0.15 & HPLC-FD & LOD: 0.01 & [165] \\
\hline & Denmark & 1999 & $228 / 300(76 \%)$ & $\begin{array}{c}0-2.9 \\
\text { Mean: } 0.12 \text {, Median: } 0.03\end{array}$ & HPLC-FD & LOD: 0.03, LOQ: 0.09 & [181] \\
\hline
\end{tabular}


Table 3. Cont.

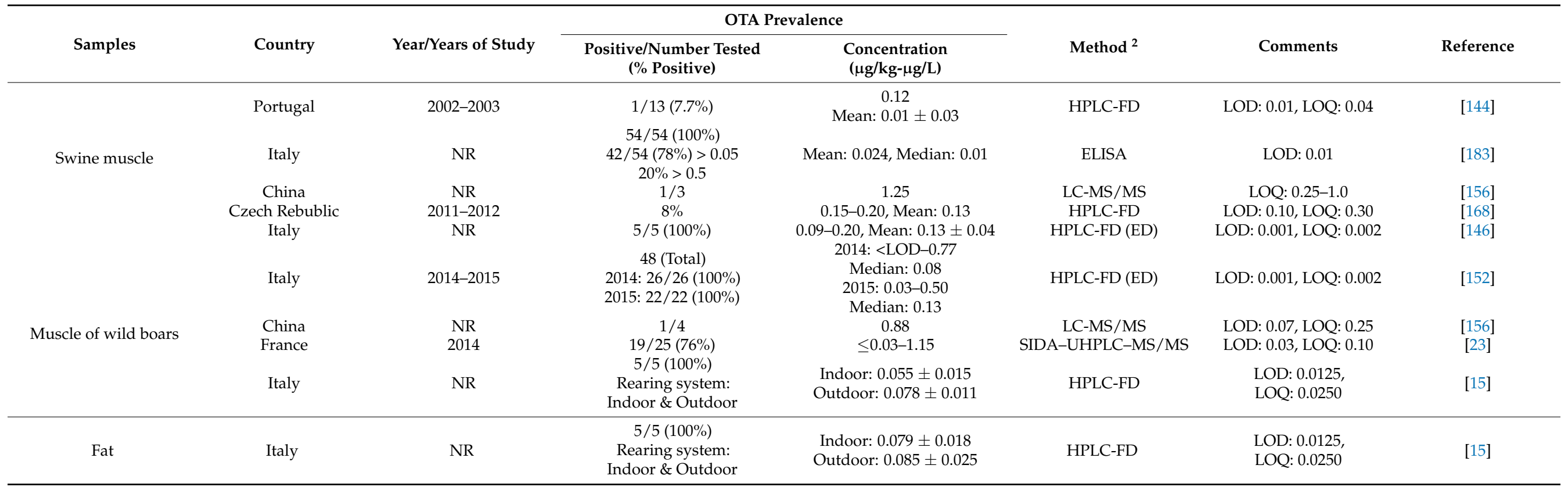

${ }^{1}$ NR: Not reported. ${ }^{2}$ Refer to Table 2 for abbreviations; UHPLC-MS/MS: Ultra-high performance liquid chromatography tandem mass spectrometry; LC-MS/MS: Liquid Chromatography tandem mass spectrometry; ED: enzymatic digestion; SIDA: Stable isotope dilution assay. 


\section{Occurrence of OTA in Pork Meat Products}

OTA is the most common mycotoxin found in processed pork meat products $[30,67,70,83]$. Table 4 summarizes OTA occurrence data in pork meat products from published studies conducted in various countries. The contamination of pork meat products with OTA may be due to the use of contaminated raw meat and offal, especially kidneys, livers, blood and blood plasma $[21,25,26]$, and secondarily to the addition of other contaminated materials such as spices [31,32]. Offal-containing sausages such as black pudding and liver sausages have been often found to be contaminated with OTA in significant concentrations [21]. However, in a recent study in Belgium, 20 black sausage samples were tested and were not found to be contaminated with OTA [169].

High differences in the occurrence of OTA in pork meat products have been observed in various countries (Table 4). High values of OTA of $158 \mu \mathrm{g} / \mathrm{kg}$ and $103.69 \mu \mathrm{g} / \mathrm{kg}$ were reported for fermented sausages in Denmark and salami in Italy, respectively [142,186]. Mitchell et al. [187] reported that most pork meat samples were found to have nondetectable OTA levels. According to a survey conducted in various European countries, the mean value of OTA recorded in various pork products was $0.052 \mu \mathrm{g} / \mathrm{kg}$ [188]. In Italy, Altafini et al. [32] analyzed 172 different salamis and found that 3 samples of spicy salamis exceeded the official Italian permitted value of $1 \mu \mathrm{g} / \mathrm{kg}$ allowed for OTA in pork meat products. The authors concluded that the high OTA levels in these samples were derived from the addition of OTA-contaminated chili pepper. Meucci et al. [15] compared the effect of the indoor and outdoor rearing system in OTA contamination in produced pork meat products. The OTA values determined by HPLC-FD analysis were $0.058 \mu \mathrm{g} / \mathrm{kg}$ and $0.537 \mu \mathrm{g} / \mathrm{kg}$ in indoor and $0.064 \mu \mathrm{g} / \mathrm{kg}$ and $0.558 \mu \mathrm{g} / \mathrm{kg}$ in outdoor salami and mortadella, respectively, indicating no significant difference between the two examined systems.

Studies on the OTA levels in fermented sausages produced from pigs fed with OTAcontaminated feed were also conducted. In a study conducted in Croatia, pigs were fed with OTA-contaminated feed (300 $\mu \mathrm{g} / \mathrm{kg}$ of feed) for 30 days [21]. The mean OTA levels were $13.82 \mu \mathrm{g} / \mathrm{kg}$ and $9.13 \mu \mathrm{g} / \mathrm{kg}$ for produced black pudding sausages and pated products, respectively. In a similar study conducted also in Croatia, the OTA levels were ranged from $4.51 \pm 0.11 \mu \mathrm{g} / \mathrm{kg}$ in smoked ham to $6.32 \pm 0.65 \mu \mathrm{g} / \mathrm{kg}$ in bacon [152].

The occurrence of OTA in contaminated meat products may also be due to the growth of OTA-producing fungi in these products [26-30,94]. Surveys in ham-manufacturing plants revealed that OTA toxigenic strains of Aspergilli and Penicillia were present in the ripening rooms [98,189]. Dall'Asta et al. [26] examined the contamination levels of hams in the inner and the outer parts and concluded that the mean OTA levels were $0.24 \mu \mathrm{g} / \mathrm{kg}$ in the inner and $0.98 \mu \mathrm{g} / \mathrm{kg}$ in the outer samples. Hams inoculated with P. nordicum yielded significantly higher amounts of OTA than those inoculated with A. ochraceus [27]. SánchezMontero et al. [24] inoculated ham samples with P. verrucosum and P. nordicum and found that the OTA levels ranged between $2.30-4.37 \mu \mathrm{g} / \mathrm{kg}$, using different $\mathrm{a}_{\mathrm{w}}$ values. In a recent study, Delgado et al. [161] inoculated raw sausages with P. nordicum, and after 26 days of ripening, the OTA levels were in the range of 1.02 to $51.06 \mu \mathrm{g} / \mathrm{kg}$.

It was also found that the growth of $A$. westerdijkiae on the salami surface produces high levels of OTA on the casing and allows its diffusion through the casing to the outer parts of sausages [30]. Furthermore, the inoculation of dry fermented sausage with $A$. westerdijkiae resulted in high levels of OTA of $1.959 \mu \mathrm{g} / \mathrm{kg}$ [70]. In sausages inoculated with strains of P. nordicum and P. verrucosum, the OTA level was found to be between $30.58 \mu \mathrm{g} / \mathrm{kg}$ and $66.91 \mu \mathrm{g} / \mathrm{kg}$ [24]. Fresh pork sausages were inoculated with $P$. nordicum, and OTA was detected on the fourth day $(10 \mu \mathrm{g} / \mathrm{kg})$ and increased significantly on the seventh day, reaching the maximum level of $135 \mu \mathrm{g} / \mathrm{kg}$ after 10 days of storage [67]. 
Table 4. OTA occurrence in pork meat products.

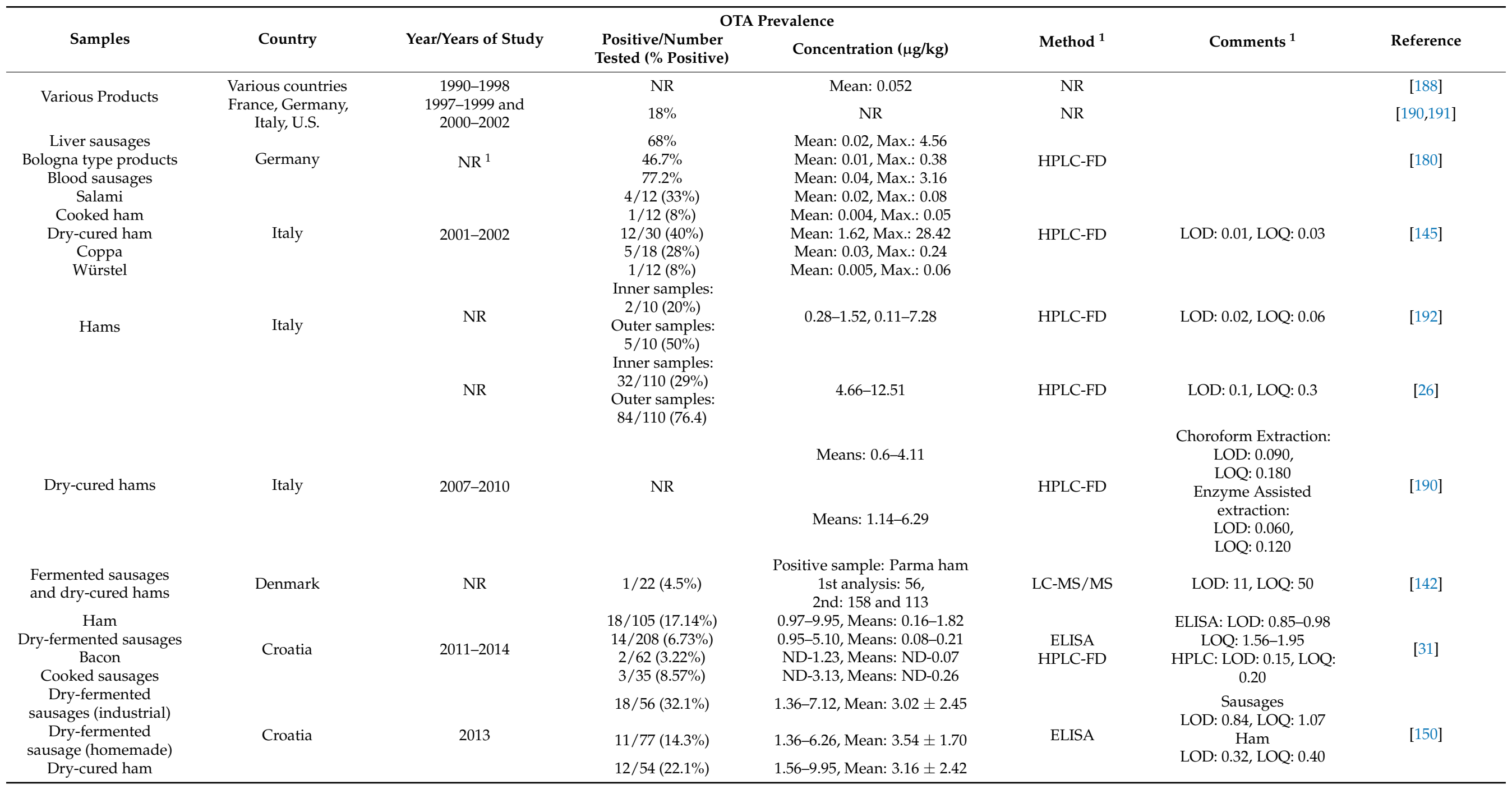


Table 4. Cont.

\begin{tabular}{|c|c|c|c|c|c|c|c|}
\hline \multirow[b]{2}{*}{ Samples } & \multirow[b]{2}{*}{ Country } & \multirow[b]{2}{*}{ Year/Years of Study } & \multicolumn{2}{|c|}{ OTA Prevalence } & \multirow[b]{2}{*}{ Method $^{1}$} & \multirow[b]{2}{*}{ Comments $^{1}$} & \multirow[b]{2}{*}{ Reference } \\
\hline & & & $\begin{array}{l}\text { Positive/Number } \\
\text { Tested (\% Positive) }\end{array}$ & Concentration $(\mu \mathrm{g} / \mathrm{kg})$ & & & \\
\hline $\begin{array}{c}\text { Salami } \\
\text { Mortadella }\end{array}$ & Italy & NR & $\begin{array}{c}\text { NR } \\
\text { Rearing system indoor } \\
\text { and outdoor }\end{array}$ & $\begin{array}{l}\text { Indoor: } 0.058 \pm 0.015 \\
\text { Outdoor: } 0.064 \pm 0.004 \\
\text { Indoor: } 0.537 \pm 0.042 \\
\text { Outdoor: } 0.558 \pm 0.016\end{array}$ & HPLC-FD & $\begin{array}{l}\text { LOD: } 0.0125 \text {, } \\
\text { LOQ: } 0.0250\end{array}$ & [15] \\
\hline $\begin{array}{c}\text { Prosciuttos } \\
\text { Fermented sausages }\end{array}$ & Croatia & NR & $\begin{array}{c}15 / 67(22.4 \%) \\
7 / 93(7.5 \%) \\
27 / 42(64.2 \%)\end{array}$ & $\begin{array}{l}\text { 2.16-6.86, Means: } 3.56-5.04 \\
\text { 2.74-4.14, Means: } 2.97-3.89\end{array}$ & ELISA & & [57] \\
\hline Hams & Italy & NR & $\begin{array}{c}<1.0 \\
14 / 42(33.4 \%) \\
1-2 \\
1 / 42(2.4 \%)>2\end{array}$ & $\begin{array}{c}0.04-0.98 \\
1.1-2, \\
2.20-2.30\end{array}$ & $\begin{array}{c}\text { HPLC-FD } \\
\text { VICAM fluorometer }\end{array}$ & $\begin{array}{l}\text { HPLC: LOD: } 0.04 \\
\text { Fluorometric: } \\
\text { LOD: } 0.7\end{array}$ & [171] \\
\hline Salami type cured meat & Italy & NR & $14 / 30(46.7 \%)$ & $\begin{array}{c}\text { 9/30 (30\%): } 0.006-0.06 \\
5 / 30(16.7 \%): 0.06-1\end{array}$ & HPLC-FD & LOD: 0.06, LOQ: 0.22 & [193] \\
\hline \multirow{3}{*}{ Salami } & \multirow{3}{*}{ Italy } & 2013 & $5 / 50(10 \%)$ & $\begin{array}{c}4 \text { samples: } 0.06-0.44 \\
1 \text { sample: } 103.69\end{array}$ & HPLC-FD & LOD: 0.06, LOQ: 0.20 & [186] \\
\hline & & 2013-2015 & $13 / 133(9.8 \%)$ & - & LC-MS/MS & LOQ: 1 & [194] \\
\hline & & 2015-2016 & $22 / 172(12.8 \%)$ & 0.07-5.66, Mean: 0.51 & HPLC-FD & LOD: 0.05, LOQ: 0.20 & [32] \\
\hline \multirow{2}{*}{$\begin{array}{c}\text { Sausages } \\
\text { Dry Fermented } \\
\text { sausages }\end{array}$} & China & 2013-2014 & $1 / 10$ & 0.5 & LC-MS/MS & LOD: 0.05, LOQ: 0.1 & [13] \\
\hline & Croatia & NR & $13 / 88(14.8 \%)$ & $\begin{array}{c}<\text { LOD- } 0.48 \\
\text { Mean: } 0.26 \pm 0.12\end{array}$ & LC-MS/MS & LOD: 0.44, LOQ: 1.44 & {$[56]$} \\
\hline \multirow{2}{*}{$\begin{array}{l}\text { "Pâté" products } \\
\text { Products with } \\
\text { porcine serum }\end{array}$} & Spain & NR & $3 / 38(7.9 \%)$ & Max.: 1.77 & HPLC-FD & LOD: 0.56, LOQ: 0.84 & [195] \\
\hline & Germany & NR & $58 / 325(17.8 \%)$ & Mean: 0.15 & ELISA and HPLC-FD & - & [196] \\
\hline
\end{tabular}

${ }^{1}$ Refer to Table 3 for abbreviations. 


\section{Risk Assessment of Human Exposure to OTA by Consumption of Pork Meat and Derived Products}

There are only a few studies on the assessment of the human exposure to OTA due to the consumption of pork meat and derived products. The Joint FAO/WHO expert committee on food additives (JECFA) established a Provisional Tolerable Weekly Intake (PTWI) of $100 \mathrm{ng} / \mathrm{kg}$ bw based on the lowest-observed-adversed-effect level (LOAEL) for renal effects in pigs [188,197]. EFSA has adopted a scientific opinion relating to OTA and derived a tolerable weekly intake (TWI) of $120 \mathrm{ng} / \mathrm{kg}$ bw (equivalent to $17 \mathrm{ng} / \mathrm{kg}$ bw /day), derived from the pig lowest observed adverse effect level (LOAEL) [8], and this was also reconfirmined in 2010 [198]. Health Canada re-evaluated the appropriateness of the EFSA TWI and established a tolerable daily intake (TDI) of $3 \mathrm{ng} / \mathrm{kg}$ bw per day (which would correspond to a TWI of $21 \mathrm{ng} / \mathrm{kg} \mathrm{bw}$ ) [14]. In the European population, dietary exposure levels for adult consumers have estimated a range from 15 to $60 \mathrm{ng} / \mathrm{kg}$ bw per week (ca. 2 to $8 \mathrm{ng} / \mathrm{kg}$ bw per day), and this range is below the established TWI. However, the exposure could be higher in children and certain cosumer groups with specific consumption habits [97,199].

According to the results of two research projects (1997-1999 and 2000-2002) $[190,191]$ on the occurrence of OTA in commodities on the European market and on dietary exposure to OTA in the EU members, pork contributed only $1 \%$ to the total estimated intake. In an early study of Frohlich et al. [166], OTA was present in the blood of people in Canada (40\%), and they concluded that a possible entry path of OTA into the human food chain was pork products. Frank [196] calculated that the daily intake of OTA by German consumers is $1.6 \mathrm{ng}$ from the consumption of sausages. In a recent study in USA, mean OTA exposure from pork in the consumer population was $0.16 \mathrm{ng} / \mathrm{kg}$ bw per day [187]. JECFA [188] estimated the intake of OTA from pork to be $1.5 \mathrm{ng} / \mathrm{kg}$ bw per week. Jorgensen [200] estimated the OTA exposure by European consumers at $45 \mu \mathrm{g} / \mathrm{kg}$ bw per week and the intake of OTA from pork at $1.5 \mathrm{ng} / \mathrm{kg}$ bw per week.

Human exposure to OTA seems to be associated predominantly with the consumption of contaminated plant-derived products and only to a minor extent with foods of animal origin [201]. However, regular consumption of certain porcine blood products contributes considerably to the level of exposure, especially in children, in which the relatively lower body weight as compared to adults results in a higher exposure per $\mathrm{kg} \mathrm{bw}$ [202].

\section{Conclusions}

OTA is produced by grown Aspergillus and Penicillium spp. in a wide variety of foods and feeds. OTA is toxigenic to animals and humans and has been classified as possibly carcinogenic to humans (Group 2B) by the IARC. In humans, OTA exposure was associated with Balkan Endemic Nephropathy, Chronic Interstitial Nephropathy and other kidney diseases, although this is not epidemiologically evident.

Pigs are the most susceptible animals to OTA exposure. Among foods of animal origin, pork meat and meat products are considered as important sources for chronic dietary exposure to OTA in humans. The EU established maximum limits for OTA in a variety of foods since 2006, but not for meat or meat products.

Various levels of OTA have been found to be present in pork meat and offal from slaughtered pigs in various countries. According to several studies of slaughtered pigs accomplished in many countries, the OTA levels were particularly high in blood serum and kidneys.

High differences in the occurrence of OTA in pork meat products have been observed in various countries. Pork products made from pig blood or organs such as the kidney or liver have often been associated with the presence of OTA. Results from these studies highlight the need to apply control OTA measures in pig feeds and establish an ML for OTA in pork meat by-products to protect human health and to constantly monitor OTA occurrence in animal-derived products. 
Author Contributions: Investigation and literature search, M.V. and A.P.; writing-original draft preparation, M.V., A.P., N.S.; writing-review and editing, A.P. and A.G. All authors have read and agreed to the published version of the manuscript.

Funding: This research received no external funding.

Conflicts of Interest: The authors declare no conflict of interest.

\section{References}

1. $\quad$ Bostan, H.B.; Danesh, N.M.; Karimi, G.; Ramezani, M.; Shaegh, S.A.M.; Youssefi, K.; Charbgoo, F.; Abnous, K.; Taghdisi, S.M. Ultrasensitive detection of ochratoxin A using aptasensors. Biosens. Bioelectron. 2017, 98, 168-179. [CrossRef] [PubMed]

2. Filazi, A.; Yurdakok-Dikmen, B.; Kuzukiran, O.; Sireli, U.T. Mycotoxins in Poultry. In Poultry Science; Manafi, M., Ed.; IntechOpen: Rijeka, Croatia, 2017.

3. el Khoury, A.; Atoui, A. Ochratoxin A: General overview and actual molecular status. Toxins 2010, 2, 461-493. [CrossRef]

4. Stoev, S.D. Studies on carcinogenic and toxic effects of ochratoxin A in chicks. Toxins 2010, 2, 649-664. [CrossRef]

5. Stoev, S.D. Long term preliminary studies on toxic and carcinogenic effect of individual or simultaneous exposure to ochratoxin A and penicillic acid in mice. Toxicon 2020, 184, 192-201. [CrossRef] [PubMed]

6. Stoev, S.D. Follow up long term preliminary studies on carcinogenic and toxic effects of ochratoxin A in rats and the putative protection of phenylalanine. Toxicon 2021, 190, 41-49. [CrossRef]

7. International Agency for Research on Cancer. Agents Classified by the IARC Monographs; IARC: Lyon, France, 2016; Volumes 1-117.

8. Commission of the European Communities (CEC). Commission Regulation (EC) No. 1881/2006 of 19 December 2006 setting maximum levels for certain contaminants in foodstuffs. Off. J. Eur. Union L 2006, 364, 5-24.

9. Di Stefano, V. Occurrence \& Risk of OTA in Food and Feed. In Encyclopedia of Food Chemistry; Melton, L., Shahidi, F., Varelis, P., Eds.; Elsevier: Amsterdam, The Netherlands, 2019; pp. 420-423.

10. Duarte, S.C.; Lino, C.M.; Pena, A. Ochratoxin A in feed of food-producing animals: An undesirable mycotoxin with health and performance effects. Vet. Microbiol. 2011, 154, 1-13. [CrossRef] [PubMed]

11. Stoev, S.D.; Goundasheva, D.; Mirtcheva, T.; Mantle, P.G. Susceptibility to secondary bacterial infections in growing pigs as an early response in ochratoxicosis. Exp. Toxicol. Pathol. 2000, 52, 287-296. [CrossRef]

12. Loh, Z.H.; Ouwerkerk, D.; Klieve, A.V.; Hungerford, N.L.; Fletcher, M.T. Toxin Degradation by Rumen Microorganisms: A Review. Toxins 2020, 12, 664. [CrossRef] [PubMed]

13. Zhao, Z.; Liu, N.; Yang, L.; Deng, Y.; Wang, J.; Song, S.; Lin, S.; Wu, A.; Zhou, Z.; Hou, J. Multi-mycotoxin analysis of animal feed and animal-derived food using LC-MS/MS system with timed and highly selective reaction monitoring. Anal. Bioanal. Chem. 2015, 407, 7359-7368. [CrossRef] [PubMed]

14. EFSA Panel on Contaminants in the Food Chain (CONTAM). Risk assessment of ochratoxin A in food. EFSA J. 2020, 18, 6113.

15. Meucci, V.; Pistoia, A.; Bertini, S.; Menozzi, A.; Intorre, L. Natural occurrence of ochratoxin a in confined reared and grazing pigs derived products. Large Anim. Rev. 2019, 25, 95-99.

16. Leiva, A.; Méndez, G.; Rodríguez, C.; Molina, A.; Granados-Chinchilla, F. Chemical assessment of mycotoxin contaminants and veterinary residues in Costa Rican animal feed. Int. J. Food Contam. 2019, 6, 5. [CrossRef]

17. Pozzo, L.; Cavallarin, L.; Nucera, D.; Antoniazzi, S.; Schiavone, A. A survey of ochratoxin A contamination in feeds and sera from organic and standard swine farms in Northwest Italy. J. Sci. Food Agric. 2010, 90, 1467-1472. [CrossRef] [PubMed]

18. Li, X.; Zhao, L.; Fan, Y. Occurrence of mycotoxins in feed ingredients and complete feeds obtained from the Beijing region of China. J. Anim. Sci. Biotechnol. 2014, 5, 37. [CrossRef] [PubMed]

19. Rosa, C.A.R.; Keller, K.M.; Keller, L.A.M.; González Pereyra, M.L.; Pereyra, C.M.; Dalcero, A.M.; Cavaglieri, L.R.; Lopes, C.W.G. Mycological survey and ochratoxin A natural contamination of swinefeedstuffs in Rio de Janeiro State, Brazil. Toxicon 2009, 53, 283-288. [CrossRef] [PubMed]

20. Battacone, G.; Nudda, A.; Pulina, G. Effects of ochratoxin A on livestock production. Toxins 2010, 2, 1796-1824. [CrossRef] [PubMed]

21. Perši, N.; Pleadin, J.; Kovačević, D.; Scortichini, G.; Milone, S. Ochratoxin A in raw materials and cooked meat products made from OTA-treated pigs. Meat Sci. 2014, 96, 203-210. [CrossRef] [PubMed]

22. Altafini, A.; Armorini, S.; Zaghini, A.; Sardi, L.; Roncada, P. Tissue distribution of ochratoxin A in pigs after administration of two-levels contaminated diets. World Mycotoxin J. 2017, 10, 263-272. [CrossRef]

23. Hort, V.; Nicolas, M.; Minvielle, B.; Maleix, C.; Desbourdes, C.; Hommet, F.; Dragacci, S.; Dervilly-Pinel, G.; Engel, E.; Guérin, T. Ochratoxin A determination in swine muscle and liver from French conventional or organic farming production systems. $J$. Chromatogr. B Analyt. Technol. Biomed. Life Sci. 2018, 1092, 131-137. [CrossRef] [PubMed]

24. Sánchez-Montero, L.; Córdoba, J.J.; Peromingo, B.; Álvarez, M.; Núñez, F. Effects of environmental conditions and substrate on growth and ochratoxin A production by Penicillium verrucosum and Penicillium nordicum: Relative risk assessment of OTA in dry-cured meat products. Food Res. Int. 2019, 121, 604-611. [CrossRef]

25. Tolosa, J.; Ruiz, M.J.; Ferrer, E.; Vila-Donat, P. Ochratoxin A: Occurrence and carry-over in meat and meat by-products. A Review. Rev. Toxicol. 2020, 37, 106-110. 
26. Dall'Asta, C.; Galaverna, G.; Bertuzzi, T.; Moseriti, A.; Pietri, A.; Dossena, A.; Marchelli, R. Occurrence of ochratoxin A in raw ham muscle, salami and dry-cured ham from pigs fed with contaminated diet. Food Chem. 2010, 120, 978-983. [CrossRef]

27. Rodríguez, A.; Rodriguez, M.; Martin, A.; Delgado, J.; Cordoba, J.J. Presence of Ochratoxin A on the Surface of Dry-Cured Iberian Ham After Initial Fungal Growth in the Drying Stage. Meat Sci. 2012, 92, 728-734. [CrossRef]

28. Berni, E.; Montagna, I.; Restivo, F.; Degola, F. Ochratoxin A Control in Meat Derivatives: Intraspecific Biocompetition between Penicillium nordicum Strains. J. Food Qual. 2017, 2017, 8370106. [CrossRef]

29. Pleadin, J.; Zadravec, M.; Brnić, D.; Perković, I.; Škrivanko, M.; Kovačević, D. Moulds and mycotoxins detected in the regional speciality fermented sausage "slavonski kulen" during a 1-year production period. Food Addit. Contam. A 2017, 34, 282-290. [CrossRef] [PubMed]

30. Parussolo, G.; Oliveira, M.S.; Valle Garcia, M.; Olivier Bernardi, A.; Lemos, J.C.; Stefanello, A.; Mallmann, C.A.; Venturini Copetti, M. Ochratoxin A production by Aspergillus westerdijkiae in Italian-type salami. Food Microbiol. 2019, 83, 134-140. [CrossRef]

31. Pleadin, J.; Malenica Staver, M.; Vahčić, N.; Kovačević, D.; Milone, S.; Saftić, L.; Scortichini, G. Survey of aflatoxin B1 and ochratoxin A occurrence in traditional meat products coming from Croatian households and markets. Food Cont. 2015, 52, 71-77. [CrossRef]

32. Altafini, A.; Fedrizzi, G.; Roncada, P. Occurrence of ochratoxin A in typical salami produced in different regions of Italy. Mycotoxin Res. 2019, 35, 141-148. [CrossRef] [PubMed]

33. Vila-Donat, P.; Marín, S.; Sanchis, V.; Ramos, A.J. A review of the mycotoxin adsorbing agents, with an emphasis on their multi-binding capacity, for animal feed decontamination. Food Chem. Toxicol. 2018, 114, 246-259. [CrossRef]

34. Agriopoulou, S.; Stamatelopoulou, E.; Varzakas, T. Advances in Occurrence, Importance, and Mycotoxin Control Strategies: Prevention and Detoxification in Foods. Foods 2020, 9, 137. [CrossRef] [PubMed]

35. Malir, F.; Ostry, V.; Pfohl-Leszkowicz, A.; Malir, J.; Toman, J. Ochratoxin A: 50 Years of Research. Toxins 2016, 8, 191. [CrossRef] [PubMed]

36. Abrunhosa, L.; Paterson, R.R.; Venâncio, A. Biodegradation of Ochratoxin A for food and feed decontamination. Toxins 2010, 2, 1078-1099. [CrossRef] [PubMed]

37. Hayat, A.; Paniel, N.; Rhouati, A.; Marty, J.-L.; Barthelmebs, L. Recent advances in ochratoxin A-producing fungi detection based on PCR methods and ochratoxin A analysis in food matrices. Food Control 2012, 26, 401-415. [CrossRef]

38. Akbar, A.; Medina, A.; Magan, N. Resilience of Aspergillus westerdijkiae Strains to Interacting Climate-Related Abiotic Factors: Effects on Growth and Ochratoxin a Production on Coffee-Based Medium and in Stored Coffee. Microorganisms 2020, 8, 1268. [CrossRef]

39. Wang, Y.; Wang, L.; Liu, F.; Wang, Q.; Selvaraj, J.N.; Xing, F.; Zhao, Y.; Liu, Y. Ochratoxin A Producing Fungi, Biosynthetic Pathway and Regulatory Mechanisms. Toxins 2016, 8, 83. [CrossRef]

40. Chuaysrinule, C.; Maneeboon, T.; Roopkham, C.; Mahakarnchanakul, W. Occurrence of aflatoxin- and ochratoxin A-producing Aspergillus species in Thai dried chilli. J. Agric. Food Res. 2020, 2, 100054. [CrossRef]

41. Hong, S.B.; Lee, M.; Kim, D.H.; Varga, J.; Frisvad, J.C.; Perrone, G.; Gomi, K.; Yamada, O.; Machida, M.; Houbraken, J.; et al. Aspergillus luchuensis, an industrially important black Aspergillus in East Asia. PLoS ONE 2013, 8, e63769. [CrossRef]

42. Davolos, D.; Pietrangeli, B. A molecular and bioinformatic study on the ochratoxin A (OTA)-producing Aspergillus affinis (section Circumdati). Mycotox Res. 2014, 30, 113-122. [CrossRef]

43. Frisvad, J.C.; Frank, M.J.; Houbraken, J.A.M.P.; Kuijpers, A.F.A.; Samson, R.A. New ochratoxin producing species in Aspergillus section Circumdati. Stud. Mycol. 2004, 50, 23-43.

44. Samson, R.; Houbraken, J.; Kuijpers, A.; Frank, J.; Frisvad, J. New ochratoxin A or sclerotium producing species in Aspergillus section Nigri. Stud. Mycol. 2004, 50, 45-61.

45. Palencia, E.R.; Hinton, D.M.; Bacon, C.W. The black Aspergillus species of maize and peanuts and their potential for mycotoxin production. Toxins 2010, 2, 300-416. [CrossRef] [PubMed]

46. Larsen, T.O.; Svendsen, A.; Smedsgaard, J. Biochemical characterization of ochratoxin A-producing strains of the genus Penicillium. Appl. Environ. Microbiol. 2001, 67, 3630-3635. [CrossRef]

47. Nguyen, H.D.T.; McMullin, D.R.; Ponomareva, E.; Riley, R.; Pomraning, K.R.; Baker, S.E.; Seifert, K.A. Ochratoxin A production by Penicillium thymicola. Fungal Biol. 2016, 120, 1041-1049. [CrossRef]

48. Chen, A.J.; Tang, D.; Zhou, Y.Q.; Sun, B.D.; Li, X.J.; Wang, L.Z.; Gao, W.W. Identification of ochratoxin A producing fungi associated with fresh and dry liquorice. PLOS ONE 2013, 8, e78285. [CrossRef]

49. Vega, F.E.; Posada, F.; Peterson, S.W.; Gianfagna, T.J.; Chaves, F. Penicillium species endophytic in coffee plants and ochratoxin A production. Mycologia 2006, 98, 31-42. [CrossRef] [PubMed]

50. Perrone, G.; Samson, R.A.; Frisvad, J.C.; Susca, A.; Gunde-Cimerman, N.; Epifani, F.; Houbraken, J. Penicillium salamii, a new species occurring during seasoning of dry-cured meat. Int. J. Food Microbiol. 2015, 19, 91-98. [CrossRef] [PubMed]

51. Stoev, S.D.; Dutton, M.; Njobeh, P.; Mosonik, J.; Steenkamp, P. Mycotoxic nephropathy in Bulgarian pigs and chickens: Complex aetiology and similarity to Balkan Endemic Nephropathy. Food Addit. Contam. A 2010, 27, 72-88. [CrossRef]

52. Pardo, E.; Marın, S.; Ramos, A.J.; Sanchis, V. Effect of water activity and temperature on mycelial growth and ochratoxin A production by isolates of Aspergillus ochraceus on irradiated green coffee beans. J. Food Prot. 2005, 68, 133-138. [CrossRef]

53. Scudamore, K.A. Prevention of ochratoxin A in commodities and likely effects of processing fractionation and animal feeds. Food Addit. Contam. A 2005, 22, 17-25. [CrossRef] 
54. Duarte, S.C.; Lino, C.M.; Pena, A. Mycotoxin food and feed regulation and the specific case of ochratoxin A: A review of the worldwide status. Food Addit. Contam. A 2010, 27, 1440-1450. [CrossRef] [PubMed]

55. Reddy, K.V.; Naveen, K.; Reddy, I.B. Incidence and Molecular Detection Of Ochratoxigenic Fungi From Indian Cereal Grains. Int. J. Pharma Bio. Sci. 2013, 4, 31-40.

56. Kudumija, N.; Vulić, A.; Lešić, T.; Vahčić, N.; Pleadin, J. Aflatoxins and ochratoxin A in dry-fermented sausages in Croatia, by LC-MS/MS. Food Addit. Contam. B 2020, 13, 225-232. [CrossRef]

57. Zadravec, M.; Vahčić, N.; Brnić, D.; Markov, K.; Frece, J.; Beck, R.; Lešić, T.; Pleadin, J. A study of surface moulds and mycotoxins in Croatian traditional dry-cured meat products. Int. J. Food Microbiol. 2020, 317, 108459. [CrossRef] [PubMed]

58. Guerre, P. Review: Worldwide Mycotoxins Exposure in Pig and Poultry Feed Formulations. Toxins 2016, 8, 350. [CrossRef] [PubMed]

59. Commission of the European Communities (CEC). Commission recommendation 2006/576/EC of 17 August 2006 on the presence of deoxynivalenol, zearalenone, ochratoxin A, T-2 and HT-2 and fumonisins in products intended for animal feeding. Off. J. Eur. Union L 2006, 229, 7-9.

60. Stoev, S.D. Foodborne mycotoxicoses, risk assessment and underestimated hazard of masked mycotoxins and joint mycotoxin effects or interaction. Environ. Toxicol. Pharmacol. 2015, 9, 794-809. [CrossRef]

61. Zachariasova, M.; Dzuman, Z.; Veprikova, Z.; Hajkova, K.; Jiru, M.; Vaclavikova, M.; Hajslova, J. Occurrence of multiple mycotoxins in European feedingstuffs, assessment of dietary intake by farm animals. Anim. Feed Sci. Technol. 2014, 193, 124-140. [CrossRef]

62. Mizakova, A.; Pipova, M.; Turek, P. The occurrence of moulds in fermented raw meat products. Czech J. Food Sci. 2002, 3, 89-94. [CrossRef]

63. Comi, G.; Orlic, S.; Redzepovic, S.; Urso, R.; Iacumin, L. Moulds isolated from Istrian dried ham at the pre-ripening and ripening level. Int. J. Food Microbiol. 2004, 96, 29-34. [CrossRef]

64. Battilani, P.; Formenti, S.; Toscani, T.; Virgili, R. Influence of abiotic parameters on ochratoxin A production by Penicillium nordicum strain in dry-cured meat model systems. Food Control 2010, 21, 1739-1744. [CrossRef]

65. Rodríguez, A.; Bernáldez, V.; Rodrígues, M.; Andrade, M.J.; Núñez, F.; Córdoba, J.J. Effect of selected protective cultures on ochratoxin A accumulation in dry cured Iberian ham during its ripening process. LWT Food Sci. Technol. 2015, 60, 923-928. [CrossRef]

66. Rodríguez, A.; Capela, D.; Medina, Á.; Córdoba, J.J.; Magan, N. Relationship between ecophysiological factors, growth and ochratoxin A contamination of dry cured sausage-based matrices. Int. J. Food Microbiol. 2015, 194, 71-77. [CrossRef] [PubMed]

67. Ferrara, M.; Magistà, D.; Lippolis, V.; Cervellieri, S.; Susca, A.; Perrone, G. Effect of Penicillium nordicum contamination rates on ochratoxin A accumulation in dry-cured salami. Food Control 2016, 67, 235-239. [CrossRef]

68. Andrade, M.J.; Peromingo, B.; Rodríguez, M. Effect of cured meat product ingredients on the Penicillium verrucosum growth and ochratoxin A production. Food Control 2019, 96, 310-317. [CrossRef]

69. Peromingo, B.; Sulyok, M.; Lemmens, M.; Rodríguez, A.; Rodríguez, M. Diffusion of mycotoxins and secondary metabolites in dry-cured meat products. Food Control 2019, 101, 144-150. [CrossRef]

70. Meftah, S.; Abid, S.; Dias, T.; Rodrigues, P. Effect of dry-sausage starter culture and endogenous yeasts on Aspergillus westerdijkiae and Penicillium nordicum growth and OTA production. Food Sci. Technol. 2018, 87, 250-258. [CrossRef]

71. Schmidt-Heydt, M.; Graf, E.; Batzler, J.; Geisen, R. The application of transcriptomics to understand the ecological reasons of ochratoxin A biosynthesis by Penicillium nordicum on sodium chloride rich dry cured food. Trends Food Sci. Technol. 2011, 22, 39-48. [CrossRef]

72. Schmidt-Heydt, M.; Graf, E.; Stoll, D.; Geisen, R. The biosynthesis of ochratoxin A by Penicillium as one mechanism for adaptation to $\mathrm{NaCl}$ rich foods. Food Microbiol. 2012, 29, 233-241. [CrossRef] [PubMed]

73. Schmidt-Heydt, M.; Stoll, D.; Geisen, R. Fungicides effectively used for growth inhibition of several fungi could induce mycotoxin biosynthesis in toxigenic species. Int. J. Food Microbiol. 2013, 166, 407-412. [CrossRef] [PubMed]

74. Stoll, D.; Schmidt-Heydt, M.; Geisen, R. Differences in the regulation of ochratoxin A by the HOG pathway in Penicillium and Aspergillus in response to high osmolar environments. Toxins 2013, 19, 1282-1298. [CrossRef] [PubMed]

75. Iacumin, L.; Milesi, S.; Pirani, S.; Comi, G.; Chiesa, L.M. Ochratoxigenic mold and ochratoxin a in fermented sausages from different areas in northern Italy: Occurrence, reduction or prevention with ozonated air. J. Food Saf. 2011, 31, 538-545. [CrossRef]

76. Iacumin, L.; Manzano, M.; Andyanto, D.; Comi, G. Biocontrol of ochratoxigenic moulds (Aspergillus ochraceus and Penicillium nordicum) by Debaryomyces hansenii and Saccharomycopsis fibuligera during speck production. Food Microbiol. 2017, 62, 188-195. [CrossRef]

77. Varga, J.; Kocsubé, S.; Tóth, B.; Frisvad, J.C.; Perrone, G.; Susca, A.; Meijer, M.; Samson, R.A. Aspergillus brasiliensis sp. nov., a biseriate black Aspergillus species with world-wide distribution. Int. J. Syst. Evol. Microbiol. 2007, 57, 1925-1932. [CrossRef] [PubMed]

78. Núñez, F.; Lara, M.S.; Peromingo, B.; Delgado, J.; Sánchez-Montero, L.; Andrade, M.J. Selection and evaluation of Debaryomyces hansenii isolates as potential bioprotective agents against toxigenic penicillia in dry-fermented sausages. Food Microbiol. 2015, 46, 114-120. [CrossRef]

79. Samson, R.A.; Hong, S.B.; Frisvad, J.C. Old and new concepts of species differentiation in Aspergillus. Med. Mycol. 2006, 44, 133-148. [CrossRef] [PubMed] 
80. Sonjak, S.; Licen, M.; Frisvad, J.C.; Gunde-Cimemrman, N. Salting of dry cured meat. A potential cause of contamination with the ochratoxin A-producing species Penicillium nordicum. Food Microbiol. 2011, 28, 1111-1116. [CrossRef] [PubMed]

81. Canel, R.S.; Wagner, J.R.; Stenglein, S.A.; Ludemann, V. Indigenous filamentous fungi on the surface of Argentinean dry fermented sausages produced in Colonia Caroya (Córdoba). Int. J. Food Microbiol. 2013, 164, 81-86. [CrossRef] [PubMed]

82. Costa, P.M.C. Identificação de Fungos Filamentosos e Quantificação de Ocratoxina A em Produtos Cárneos ao Longo do Período de Cura. Master's Thesis, Instituto Politécnico de Bragança, Bragança, Portugal, 2014.

83. Vila, G.S.; Pose, G.N.; Segura, J.A.; Ludemann, V. Diversidad de hongos filamentosos en el emplume de embutidos secos producidos en la región pampeana. SNS Servicio Nacional de Sanidad 2016, 10, 40-49.

84. Vipotnik, Z.; Rodríguez, A.; Rodrigues, P. Aspergillus westerdijkiae as a major ochratoxin A risk in dry-cured ham based-media. Int. J. Food Microbiol. 2017, 241, 244-251. [CrossRef] [PubMed]

85. Iacumin, L.; Arnoldi, M.; Comi, G. Effect of a Debaryomyces hansenii and Lactobacillus buchneri Starter Culture on Aspergillus westerdijkiae Ochratoxin a Production and Growth during the Manufacture of Short Seasoned Dry-Cured Ham. Microorganisms 2020, 8, 1623. [CrossRef] [PubMed]

86. Meftah, S.; Abid, S.; Dias, T.; Rodrigues, P. Mechanisms underlying the effect of commercial starter cultures and a native yeast on ochratoxin A production in meat products. LWT Food Sci. Technol. 2019, 117, 108611. [CrossRef]

87. Rodríguez, A.; Medina, Á.; Córdoba, J.J.; Magan, N. The influence of salt ( $\mathrm{NaCl})$ on ochratoxin A biosynthetic genes, growth and ochratoxin A production by three strains of Penicillium nordicum on a dry-cured ham-based medium. Int. J. Food Microbiol. 2014, 178, 113-119. [CrossRef] [PubMed]

88. Cebrián, E.; Rodríguez, M.; Peromingo, B.; Bermúdez, E.; Núñez, N. Efficacy of the combined protective cultures of Penicillium chrysogenum and Debaryomyces hansenii for the control of ochratoxin A hazard in dry-cured ham. Toxins 2019, 11, 710. [CrossRef] [PubMed]

89. Peromingo, B.; Núñez, F.; Rodríguez, A.; Alía, A.; Andrade, M.J. Potential of yeasts isolated from dry-cured ham to control ochratoxin A production in meat models. Int. J. Food Microbiol. 2018, 268, 73-80. [CrossRef] [PubMed]

90. World Health Organization (WHO); Food and Agriculture Organization (FAO). Ochratoxin A. In Safety Evaluation of Certain Mycotoxins in Food; WHO: Geneva, Switzerland, 2001; Volume 47, pp. 281-415.

91. Tawakkol, W.N.; Khafaga, I. Fungal Contamination of Meat and Its Environment With Special Reference To The Strains Producing Aflatoxins, Ochratoxins, Proteinase and Lipase Enzymes. New Egypt. J. Microbiol. 2007, 17, 1-14. [CrossRef]

92. Comi, G.; Manzano, M.; Brichese, R.; Iacumin, L. New case of spoilage in San Daniele Dry Cured Hams. J. Food Saf. 2014, 34, 263-269. [CrossRef]

93. Scaramuzza, N.; Diaferia, C.; Berni, E. Monitoring the mycobiota of three plants manufacturing Culatello (a typical Italian meat product). Int. J. Food Microbiol. 2015, 16, 78-85. [CrossRef]

94. Iacumin, L.; Chiesa, L.; Boscolo, D.; Manzano, M.; Cantoni, C.; Orlic, S.; Comi, G. Moulds and ochratoxin A on surfaces of artisanal and industrial dry sausages. Food Microbiol. 2009, 26, 65-70. [CrossRef] [PubMed]

95. Battilani, P.; Pietri, A.; Giorni, P.; Formenti, S.; Bertuzzi, T.; Toscani, T.; Virgili, R.; Kozakiewicz, Z. Penicillium populations in dry-cured ham manufacturing plants. J. Food Prot. 2007, 70, 975-980. [CrossRef] [PubMed]

96. Castella, G.; Larsen, T.O.; Cabanes, J.; Schmidt, H.; Alberesi, A.; Niessen, L.; Farber, P.; Geisen, R. Molecular characterization of ochratoxin A producing strains of the genus Penicillium. Syst. Appl. Microbiol. 2002, 25, 74-83. [CrossRef]

97. European Food Safety Authority (EFSA). Opinion of the scientific panel on contaminants in the food chain on request from the commission related to ochratoxin A in food. EFSA J. 2006, 4, 365. [CrossRef]

98. Bogs, C.; Battilani, P.; Geisen, R. Development of a molecular detection and differentiation system for ochratoxin A producing penicillium species and its application to analyse the occurrence of Penicillium nordicum in cured meats. Int. J. Food Microbiol. 2006, 107, 39-47. [CrossRef] [PubMed]

99. Dobson, A.D.W. Mycotoxins in cheese. In Cheese: Chemistry, Physics and Microbiology, 4th ed.; McSweeney, P.L.H., Fox, P.F., Cotter, P., Everett, D.W., Eds.; Elsevier: New York, NY, USA, 2017; pp. 595-601.

100. Sørensen, L.M.; Jacobsen, T.; Nielsen, P.V.; Frisvad, J.C.; Koch, A.G. Mycobiota in the n processing areas of two different meat products. Int. J. Food Microb. 2008, 24, 58-64. [CrossRef] [PubMed]

101. Comi, G.; Chiesa, L.; Panseri, S.; Orlic, S.; Iacumin, L. Evaluation of different methods to prevent Penicillium nordicum growth on and ochratoxin A production in country-style sausages. World Mycotoxin J. 2013, 6, 411-418. [CrossRef]

102. Bittner, A.; Cramer, B.; Humpf, H.U. Matrix binding of ochratoxin A during roasting. J. Agric. Food Chem. 2013, 61, 12737-12743. [CrossRef] [PubMed]

103. Kőszegi, T.; Poór, M. Ochratoxin A: Molecular Interactions, Mechanisms of Toxicity and Prevention at the Molecular Level. Toxins 2016, 8, 111. [CrossRef]

104. Dahal, S.; Lee, H.J.; Gu, K.; Ryu, D. Heat stability of ochratoxin A in an aqueous buffered model system. J. Food Protect. 2016, 79, 1748-1752. [CrossRef] [PubMed]

105. Sueck, F.; Hemp, V.; Specht, J.; Torres, O.; Cramer, B.; Humpf, H.U. Occurrence of the Ochratoxin a Degradation Product 2'R-Ochratoxin A in Coffee and Other Food: An Update. Toxins 2019, 11, 329. [CrossRef]

106. Pleadin, J.; Perši, N.; Kovačević, D.; Vulić, A.; Frece, J.; Markov, K. Ochratoxin A reduction in meat sausages using processing methods practiced in households. Food Addit. Contam. B 2014, 7, 239-246. [CrossRef] 
107. Di Stefano, V.; Pitonzo, R.; Avellone, G. Effect of gamma irradiation on aflatoxins and ochratoxin a reduction in almond samples. J. Food Res. 2014, 3, 113-118. [CrossRef]

108. Ouf, S.A.; Basher, A.H.; Mohamed, A.A. Inhibitory effect of double atmospheric pressure argon cold plasma on spores and mycotoxin production of Aspergillus niger contaminating date palm fruits. J. Sci. Food Agric. 2015, 95, 3204-3210. [CrossRef]

109. Leitao, A.L. Occurrence of Ochratoxin A in Coffee: Threads and Solutions-A Mini-Review. Beverages 2019, 5, 36. [CrossRef]

110. Marin, D.E.; Taranu, I. Ochratoxin A and its effects on immunity. Toxin Rev. 2015, 34, 11-20. [CrossRef]

111. Wang, L.; Zhang, Q.; Yan, Z.; Tan, Y.; Zhu, R.; Yu, D.; Yang, H.; Wu, A. Occurrence and Quantitative Risk Assessment of Twelve Mycotoxins in Eggs and Chicken Tissues in China. Toxins 2018, 10, 477. [CrossRef] [PubMed]

112. Heussner, A.H.; Bingle, L.E. Comparative Ochratoxin Toxicity: A Review of the Available Data. Toxins 2015, 7, 4253-4282. [CrossRef]

113. Bondy, G.S.; Caldwell, D.S.; Aziz, S.A.; Coady, L.C.; Armstrong, C.L.; Curran, I.H.; Koffman, R.L.; Kapal, K.; Lefebvre, D.E.; Mehta, R. Effects of chronic ochratoxin A exposure on p53 heterozygous and p53 homozygous mice. Toxicol. Pathol. 2015, 43, 715-729. [CrossRef] [PubMed]

114. Bondy, G.S.; Coady, L.; Ross, N.; Caldwell, D.; Gannon, A.M.; Kwong, K.; Hayward, S.; Lefebvre, D.E.; Liston, V.; Raju, J.; et al. A reproductive and developmental screening study of the fungal toxin ochratoxin A in Fischer rats. Mycotoxin Res. 2018, 34, 241-255. [CrossRef]

115. Enciso, J.M.; López de Certain, A.; Pastor, L.; Azqueta, A.; Vettorazzi, A. Is oxidative stress involved in the sex-dependent response to ochratoxin A renal toxicity? Food Chem. Toxicol. 2018, 116, 379-387. [CrossRef]

116. Rached, E.; Hard, G.C.; Blumbach, K.; Weber, K.; Draheim, R.; Lutz, W.K.; Ozden, S.; Steger, U.; Dekant, W.; Mally, A. Ochratoxin A: 13-week oral toxicity and cell proliferation in male F344/N rats. Toxicol. Sci. 2007, 97, 288-298. [CrossRef]

117. Mally, A.; Pepe, G.; Ravoori, S.; Fiore, M.; Gupta, R.C.; Dekant, W.; Mosesso, P. Ochratoxin A causes DNA damage and cytogenetic effects but no DNA adducts in rats. Chem. Res. Toxicol. 2005, 18, 1253-1261. [CrossRef] [PubMed]

118. Cariddi, L.N.; Escobar, F.M.; Sabini, M.C.; Campra, N.A.; Bagnis, G.; Decote-Ricardo, D.; Freire-de-Lima, C.G.; Mañas, F.; Sabini, L.I.; Dalcero, A.M. Phenolic acid protects of renal damage induced by ochratoxin A in a 28-days-oral treatment in rats. Environ. Toxicol. Pharmacol. 2016, 43, 105-111. [CrossRef] [PubMed]

119. Arbillaga, L.; Azqueta, A.; Ezpeleta, O.; López de Certain, A. Oxidative DNA damage induced by Ochratoxin A in the HK-2 human kidney cell line: Evidence of the relationship with cytotoxicity. Mutagenesis 2007, 22, 35-42. [CrossRef] [PubMed]

120. Abdu, S.; Ali, A.; Ansari, S. Cytotoxic effect of ochratoxin A on the renal corpuscles of rat kidney: Could ochratoxin A cause kidney failure? Histol. Histopathol. 2011, 26, 543-549. [CrossRef] [PubMed]

121. Pastor, L.; Vettorazzi, A.; Enciso, J.M.; González-Peñas, E.; García-Jalón, J.A.; Monreal, J.I.; López de Certain, A. Sex differences in ochratoxin a toxicity in F344 rats after 7 and 21 days of daily oral administration. Food Chem. Toxicol. 2018, 111, 363-373. [CrossRef]

122. Maroli, N.; Jayakrishnan, A.; Ramalingam Manoharan, R.; Kolandaivel, P.; Krishna, K. Combined Inhibitory Effects of Citrinin, Ochratoxin-A, and T-2 Toxin on Aquaporin-2. J. Phys. Chem. B 2019, 123, 5755-5768. [CrossRef]

123. Stoev, S.D.; Gundasheva, D.; Zarkov, I.; Mircheva, T.; Zapryanova, D.; Denev, S.; Mitev, Y.; Daskalov, H.; Dutton, M.; Mwanza, M.; et al. Experimental mycotoxic nephropathy in pigs provoked by a mouldy diet containing ochratoxin A and fumonisin B1. Exp. Toxicol. Pathol. 2012, 64, 733-741. [CrossRef] [PubMed]

124. Stoev, S.D.; Denev, S.; Dutton, M.; Njobeh, P.; Mosonik, J.; Steenkamp, P.; Petkov, I. Complex etiology and pathology of mycotoxic nephropathy in South African pigs. Mycotox. Res. 2010, 26, 31-46. [CrossRef] [PubMed]

125. Zhao, T.; Shen, X.L.; Chen, W.; Liao, X.; Yang, J.; Wang, Y.; Zou, Y.; Fang, C. Advances in research of nephrotoxicity and toxic antagonism of Ochratoxin, A. Toxin Rev. 2017, 36, 39-44. [CrossRef]

126. Tanchev, Y.; Evstatiev, Z.; Dorossiev, D.; Pencheva, J.; Tzvetkova, G.S. Studies on the nephritides in the District of Vratza. Savremena Med. 1956, 7, 14-29.

127. World Health Organization; International Agency for Research on Cancer. IARC Monographs on the Evaluation of Carcinogenic Risks to Humans: Some Naturally; IARC: Lyon, France, 1993; pp. 489-521.

128. Pfohl-Leszkowicz, A.; Vrabcheva, T.; Petkova-Bocharova, T.; Garren, L.; Grosso, F.; Nikolov, I.; Dragacci, S.; Chernozemsky, I.N.; Castegnaro, M. Analysis of Ochratoxin a in Serum, Urine and Food Consumed by Inhabitants from an Area with Balkan Endemic Nephropathy: A One Month Follow-up Study. In Mycotoxins and Phycotoxins: Advances in Determination, Toxicology and Exposure Management, Proceedings of the XIth International Symposium on Mycotoxins and Phytotoxins, Wageningen, The Netherlands, 17-21 May 2006; Njapau, H., Trujillo, C., van Egmond, H.P., Park, L.D., Eds.; Wageningen Academic Publishers: Wageningen, The Netherlands; Bethesda, MD, USA, 2006.

129. Staneva, R.; Rukova, B.; Hadjidekova, S.; Nesheva, D.; Antonova, O.; Dimitrov, P.; Simeonov, V.; Stamenov, G.; Cukuranovic, R.; Cukuranovic, J.; et al. Whole genome methylation array analysis reveals new aspects in Balkan endemic nephropathy etiology. BMC Nephrol. 2013, 16, 225. [CrossRef] [PubMed]

130. Kocic, G.; Cukuranovic, J.; Stoimenov, T.J.; Cukuranovic, R.; Djordjevic, V.; Bogdanovic, D.; Stefanovic, V. Global and specific histone acetylation pattern in patients with Balkan endemic nephropathy, a worldwide disease. Ren. Fail. 2014, 36, 1078-1082. [CrossRef] [PubMed]

131. Stoev, D.S. Balkan Endemic Nephropathy—Still continuing enigma, risk assessment and underestimated hazard of joint mycotoxin exposure of animals or humans. Chem. Biol. Interact. 2017, 261, 63-79. [CrossRef] [PubMed] 
132. Grollman, A.P. Aristolochic acid nephropathy: Harbinger of a global iatrogenic disease. Environ. Mol. Mutagen. 2013, 54, 1-7. [CrossRef] [PubMed]

133. Gifford, F.J.; Gifford, R.M.; Eddleston, M.; Neeraj, D. Endemic nephropathy around the world. Kidney Int. Rep. 2017,2 , $282-292$. [CrossRef] [PubMed]

134. Jadot, I.; Decleves, A.-E.; Nortier, J.; Caron, N. An integrated view of aristolochic acid nephropathy: Update of the literature. Int. J. Mol. Sci. 2017, 18, 297. [CrossRef]

135. Maaroufi, K.; Achour, A.; Hammami, M. Ochratoxin A in human blood in relation to nephropathy in Tunisia. Hum. Exp. Toxicol. 1995, 14, 609-614. [CrossRef] [PubMed]

136. Palabiyik, S.S.; Erkekoglu, P.; Zeybek, N.D.; Kızılgun, M.; Sahin, G.; Giray, B.K. Ochratoxin A causes oxidative stress and cell death in rat liver. World Mycotoxin J. 2012, 5, 377-384. [CrossRef]

137. Rašić, D.; Micek, V.; Klarić, M.; Peraica, M. Oxidative stress as a mechanism of combined OTA and CTN toxicity in rat plasma, liver and kidney. Hum. Exp. Toxicol. 2019, 38, 434-445. [CrossRef] [PubMed]

138. Van Dorp, D.R.; Malleis, J.M.; Sullivan, B.P.; Klein, M.D. Teratogens inducing congenital abdominal wall defects in animal models. Pediatr. Surg. Int. 2010, 26, 127-139. [CrossRef]

139. Galtier, P. Pharmacokinetics of ochratoxin A in Animals. IARC Sci. Publ. 1991, 115, 187-200.

140. Singapore Food Agency (SFA). Maximum Residue Limits Established for Mercury, Bromate and Mycotoxins in Food. Available online: https:/ / www.sfa.gov.sg/docs/default-source/default-document-library/circular---maximum-residue-limits-formercury-bromate-and-mycotoxins.pdf (accessed on 12 January 2021).

141. Commission Regulation (EU). 2015/1137 of 13 July 2015 amending Regulation (EC) No 1881/2006 as regards the maximum level of Ochratoxin A in Capsicum spp. spices. Off. J. Eur. Union 2015, 185, 11-12.

142. Meulenberg, E.P. Immunochemical Methods for Ochratoxin a Detection: A Review. Toxins 2012, 4, 244-266. [CrossRef]

143. Sørensen, L.M.; Mogensen, J.; Nielsen, K.F. Simultaneous determination of ochratoxin A, mycophenolic acid and fumonisin B(2) in meat products. Anal. Bioanal. Chem. 2010, 398, 1535-1542. [CrossRef]

144. Duarte, S.C.; Lino, C.M.; Pena, A. Novel IAC-LC-ESI-MS(2) analytical set-up for ochratoxin A determination in pork. Food Chem. 2013, 138, 1055-1061. [CrossRef] [PubMed]

145. Guillamont, E.M.; Lino, C.M.; Baeta, M.L.; Pena, A.S.; Silveira, M.I.N.; Vinuesa, J.M. A comparative study of extraction apparatus in HPLC analysis of ochratoxin A in muscle. Anal. Bioanal. Chem. 2005, 383, 570-575. [CrossRef] [PubMed]

146. Pietri, A.; Bertuzzi, T.; Gualla, A.; Piva, G. Occurrence of ochratoxin a in raw ham muscles and in pork products from Northern Italy. Ital. J. Food Sci. 2006, 18, 99-106.

147. Giacomo, L.; Michele, V.; Guido, F.; Danilo, M.; Luigi, I.; Valentina, M. Determination of ochratoxin A in pig tissues using enzymatic digestion coupled with high-performance liquid chromatography with a fluorescence detector. MethodsX 2016, 3, 171-177. [CrossRef] [PubMed]

148. De Santis, B.; Gregori, E.; Debegnach, F.; Moracci, G.; Saitta, C.; Brera, C. Determination of ochratoxin A in pork meat products: Single laboratory validation method and preparation of homogeneous batch materials. Mycotoxin Res. 2020, 36, $235-241$. [CrossRef] [PubMed]

149. Polovinski-Horvatovic, M.; Radovic, I.; Glamocic, D.; Jajic, I.; Krstovic, S.; Mirkov, M.; Vasiljevic, V. The occurrence of ochratoxin A in kidneys of healthy pigs from Vojvodina province, Serbia. In Proceedings of the IOP Conference Series: Earth and Environmental Science, Proceedings of the 60th International Meat Industry Conference MEATCON2019, Kopaonik, Serbia, 22-25 September 2019; Volume 333, p. 012095.

150. Rodrigues, P.; Silva, D.; Costa, P.; Abrunhosa, L.; Venâncio, A.; Teixeira, A. Mycobiota and mycotoxins in Portuguese pork, goat and sheep dry-cured hams. Mycotoxin Res. 2019, 35, 405-412. [CrossRef]

151. Vulić, A.; Vahčić, N.; Hengl, B.; Gross-Bošković, A.; Jurković, M.; Kudumija, N.; Pleadin, J. Assessment of possible human exposure to ochratoxin A in Croatia due to the consumption of dry-cured and fermented meat products. Food Addit. Contam. A 2016, 33, 1428-1434. [CrossRef]

152. Pleadin, J.; Perši, N.; Kovačević, D.; Vahčić, N.; Scortichini, G.; Milone, S.; Perši, N.; Kovačević, D.; Vahčić, N.; Scortichini, G.; et al. Ochratoxin A in traditional dry-cured meat products produced from sub-chronic-exposed pigs. Food Addit. Contam. A 2013, 30, 1827-1836. [CrossRef] [PubMed]

153. Luci, G.; Intorre, L.; Ferruzzi, G.; Mani, D.; Giuliotti, L.; Pretti, C.; Tognetti, R.; Bertini, S.; Meucci, V. Determination of ochratoxin A in tissues of wild boar (Sus scrofa L.) by enzymatic digestion (ED) coupled to high-performance liquid chromatography with a fluorescence detector (HPLC-FLD). Mycotoxin Res. 2018, 34, 1-8. [CrossRef]

154. Pietri, A.; Gualla, A.; Rastelli, S.; Bertuzzi, T. Enzyme-assisted extraction for the HPLC determination of ochratoxin A in pork and dry-cured ham. Food Addit. Contam. A 2011, 28, 1717-1723. [CrossRef]

155. Luan, C.; Wang, L.; Chen, F.; Wang, S.; Zhao, L.; Shao, L. Determination of Ochratoxin A in Pig Muscle Using Dispersive Liquid-liquid Microextraction Combined with High-Performance Liquid Chromatography. Food Anal. Methods 2016, 9, 1490-1494. [CrossRef]

156. Chen, D.; Cao, X.; Tao, Y.; Wu, Q.; Pan, Y.; Huang, L.; Wang, X.; Wang, Y.; Peng, D.; Liu, Z.; et al. Development of a sensitive and robust liquid chromatography coupled with tandem mass spectrometry and a pressurized liquid extraction for the determination of aflatoxins and ochratoxin A in animal derived foods. J. Chromatogr. A 2012, 1253, 110-119. [CrossRef] [PubMed] 
157. Cao, X.; Li, X.; Li, J.; Niu, Y.; Shi, L.; Fang, Z.; Zhang, T.; Ding, H. Quantitative determination of carcinogenic mycotoxins in human and animal biological matrices and animal-derived foods using multi-mycotoxin and analyte-specific high performance liquid chromatography-tandem mass spectrometric methods. J. Chromatogr. B Analyt. Technol. Biomed. Life Sci. 2018, 15, 191-200. [CrossRef]

158. De Saeger, S.; Dumoulin, F.; Van Peteghem, C. Quantitative determination of ochratoxin A in kidneys by liquid chromatography/mass spectrometry. Rapid Commun. Mass Spectrom. 2004, 18, 2661-2668. [CrossRef]

159. Brera, C.; Pannunzi, E.; Guarino, C.; Debegnach, F.; Gregori, E.; De Santis, B. Ochratoxin A Determination in Cured Ham By High Performance Liquid Chromatography Fluorescence Detection And Ultra Performance Liquid Chromatography Tandem Mass Spectrometry: A Comparative Study. J. Liq. Chromatogr. Relat. 2014, 37, 2036-2045. [CrossRef]

160. Hou, Y.; Zhou, J.; Li, Y.; Xie, J.; Zhou, L.; Lv, F. Determination of Ochratoxin A in Pig Kidneys by Immunoaffinity Cleanup and Ultra-High Performance Liquid Chromatography. J. AOAC Int. 2015, 98, 1566-1570. [CrossRef]

161. Taleuzzaman, M.; Ali, S.; Gilani, S.J.; Imam, S.S.; Hafeez, A. Ultra Performance Liquid Chromatography (UPLC)—A Review. Austin J. Anal. Pharm. Chem. 2015, 2, 1056.

162. Delgado, J.; Rondán, J.J.; Núñez, F.; Rodríguez, A. Influence of an industrial dry-fermented sausage processing on ochratoxin A production by Penicillium nordicum. Int. J. Food Microbiol. 2021, 339, 109016. [CrossRef]

163. Stoev, S.D.; Paskalev, M.; MacDonald, S.; Mantle, P.G. Experimental one year ochratoxin A toxicosis in pigs. Exp. Toxicol. Pathol. 2002, 53, 481-487. [CrossRef] [PubMed]

164. Tkaczyk, A.; Jedziniak, P. Mycotoxin Biomarkers in Pigs-Current State of Knowledge and Analytics. Toxins 2021, $13,586$. [CrossRef] [PubMed]

165. Curtui, V.G.; Gareis, M.; Usleber, E.; Märtlbauer, E. Survey of Romanian slaughtered pigs for the occurrence of mycotoxins ochratoxins A and B, and zearalenone. Food Addit. Contam. 2001, 18, 730-738. [CrossRef] [PubMed]

166. Curtui, V.G.; Gareis, M. A simple HPLC method for the determination of the mycotoxins ochratoxin A and B in blood serum of swine. Food Addit. Contam. 2001, 18, 635-643. [CrossRef] [PubMed]

167. Frohlich, A.A.; Marquardt, R.R.; Ominski, K.H. Ochratoxin A as a contaminant in the human food chain: A Canadian perspective. IARC Sci. Publ. 1991, 115, 139-143.

168. Milićević, D.; Jurić, V.; Stefanović, S.; Jovanović, M.; Janković, S. Survey of Slaughtered Pigs for Occurrence of Ochratoxin A and Porcine Nephropathy in Serbia. Int. J. Mol. Sci. 2008, 9, 2169-2183. [CrossRef]

169. Skarkova, J.; Ostry, V.; Malir, F.; Roubal, T. Determination of Ochratoxin A in Food by High Performance Liquid Chromatography. Anal. Lett. 2013, 46, 1495-1504. [CrossRef]

170. Tangni, E.K.; Masquelier, J.; Van Hoeck, E. Determination of ochratoxin A in edible pork offal: Intra-laboratory validation study and estimation of the daily intake via kidney consumption in Belgium. Mycotoxin Res. 2021, 37, 79-87. [CrossRef]

171. Toscani, T.; Moseriti, A.; Dossena, A.; Dall'Asta, C.; Simoncini, N.; Virgili, R. Determination of ochratoxin A in dry-cured meat products by a HPLC-FLD quantitative method. J. Chromatogr. B 2007, 855, 242-248. [CrossRef]

172. Tam, J.; Pantazopoulos, P.; Scott, P.M.; Moisey, J.; Dabeka, R.W.; Richard, I.D. Application of isotope dilution mass spectrometry: Determination of ochratoxin A in the Canadian Total Diet Study. Food Addit. Contam. A 2011, 28, 754-761. [CrossRef]

173. Petkova-Bocharova, T.; Adlouni, C.; Faucet, V.; Pfohl-Leszkowicz, A.; Mantle, P. Analysis for DNA adducts, ochratoxin a content and enzyme expression in kidneys of pigs exposed to mild experimental chronic ochratoxicosis. Facta Univ. Med. Biol. 2003, 10, 111-115.

174. Malagutti, L.; Zannotti, M.; Scampini, A.; Sciaraffia, F. Effects of ochratoxin A on heavy pig production. Anim. Res. 2005, 54, 179-184. [CrossRef]

175. Raja, A.V.; Saikumar, G.; Rinku, S.; Dwivedi, P. Ochratoxicosis in Swine: Clinical and pathological changes following prolonged exposure to Ochratoxin A. Indian J. Anim. Sci. 2008, 78, 922-928.

176. Bertuzzi, V.; Gualla, A.; Morlacchini, M.; Pietri, A. Direct and indirect contamination with ochratoxin A of ripened pork products. Food Control 2013, 34, 79-83. [CrossRef]

177. Pleadin, J.; Kudumija, N.; Kovačević, D.; Scortichini, G.; Milone, S.; Kmetič, I. Comparison of ochratoxin A levels in edible pig tissues and in biological fluids after exposure to a contaminated diet. Mycotoxin Res. 2016, 32, 145-151. [CrossRef]

178. Stoev, S.D.; Stoeva, J.; Anguelov, G.; Hald, B.; Creppy, E.E.; Radic, B. Haematological, biochemical and toxicological investigations in spontaneous cases with different frequency of porcine nephropathy in Bulgaria. J. Vet. Intern. 1998, 45, 229-236. [CrossRef] [PubMed]

179. Stoev, S.D.; Hald, B.; Mantle, P. Porcine nephropathy in Bulgaria: A progressive syndrome of complex of uncertain (mycotoxin) etiology. Vet. Rec. 1998, 142, 190-194. [CrossRef] [PubMed]

180. Dragacci, S.; Grosso, F.; Bire, R.; Fremy, J.M.; Coulon, S. A French monitoring programme for determining ochratoxin A occurrence in pig kidneys. Nat. Toxins 1999, 7, 167-173. [CrossRef]

181. Gareis, M.; Scheuer, R. Ochratoxin A in meat and meat products. Archiv. Fur. Lebensmittelhyg. 2000, 51, 102-104.

182. Jørgensen, K.; Petersen, A. Content of ochratoxin A in paired kidney and meat samples from healthy Danish slaughter pigs. Food Addit. Contam. 2002, 19, 562-567. [CrossRef] [PubMed]

183. Monaci, L.; Tantillo, G.; Palmisano, F. Determination of ochratoxin A in pig tissues by liquid-liquid extraction and clean-up and high-performance liquid chromatography. Anal. Bioanal. Chem. 2004, 378, 1777-1782. [CrossRef] [PubMed] 
184. Matrella, R.; Monaci, L.; Milillo, M.A.; Palmisano, F.; Tantillo, M.G. Ochratoxin A determination in paired kidneys and muscle samples from swines slaughtered in southern Italy. Food Control 2006, 17, 114-117. [CrossRef]

185. Ceci, E.; Bozzo, G.; Bonerba, E.; Di Pinto, A.; Tantillo, M.G. Ochratoxin A detection by HPLC in target tissues of swine and cytological and histological analysis. Food Chem 2007, 105, 364-368. [CrossRef]

186. Jørgensen, K. Survey of pork, poultry, coffee, beer and pulses for ochratoxin A. Food Addit. Contam. 1998, 15, 550-554. [CrossRef] [PubMed]

187. Armorini, S.; Altafini, A.; Zaghini, A.; Roncada, P. Ochratoxin A in artisan salami produced in Veneto (Italy). Food Addit. Contam. B 2016, 9, 9-14. [CrossRef]

188. Mitchell, N.J.; Chen, C.; Palumbo, J.D.; Bianchini, A.; Cappozzo, J.; Stratton, J.; Ryu, D.; Wu, F. A risk assessment of dietary Ochratoxin a in the United States. Food Chem. Toxicol. 2017, 100, 265-273. [CrossRef]

189. Expert Committee on Food Additives (JECFA); Food and Agriculture Organization (FAO); World health Organization (WHO). Safety Evaluation of Certain Mycotoxins in Food; Food Additive Series 47; FAO: Rome, Italy, 2001; pp. $281-415$.

190. Alapont, C.; López-Mendoza, M.C.; Gil, J.V.; Martínez-Culebras, P.V. Mycobiota and toxigenic Penicillium species on two Spanish dry-cured ham manufacturing plants. Food Addit. Contam. A 2014, 31, 93-104. [CrossRef] [PubMed]

191. SCOOP-Task 3.2.2.; European Commission. Assessment of Dietary Intake of Ochratoxin A by the Population in EU Member States, Report EUR 17523 EN 1997, Risk Assessment of Aflatoxin, 1997. Available online: https:/ /orbit.dtu.dk/en/publications/ assessment-of-dietary-intake-of-ochratoxin-a-by-the-population-of (accessed on 26 January 2021).

192. SCOOP-Task 3.2.7. Scientific Co-Operation on Question Relating to Food. (Directive 93/5/EEC). Assessment of Dietary Intake of Ochratoxin Aby the Population of EU Member States, 2002. Available online: https://ec.europa.eu/food/system/files/2016-10/ cs_contaminants_catalogue_ochratoxin_task_3-2-7_en.pdf (accessed on 26 January 2021).

193. Chiavaro, E.; Lepiani, A.; Colla, F.; Bettoni, P.; Pari, E.; Spotti, E. Ochratoxin A determination in ham by immunoaffinity clean-up and a quick fluorimetric method. Food Adict. Contam. 2002, 19, 575-579. [CrossRef]

194. Monaci, L.; Palmisano, F.; Matrella, R.; Tantillo, G. Determination of ochratoxin A at part-per-trillion level in Italian salami by immunoaffinity clean-up and high-performance liquid chromatography with fluorescence detection. J. Chromatogr. A 2005, 1090, 184-187. [CrossRef] [PubMed]

195. Merla, C.; Andreoli, G.; Garino, C.; Vicari, N.; Tosi, G.; Guglielminetti, M.L.; Moretti, A.; Biancardi, A.; Arlorio, M.; Fabbi, M. Monitoring of ochratoxin A and ochratoxin-producing fungi in traditional salami manufactured in Northern Italy. Mycotoxin Res. 2018, 34, 107-116. [CrossRef] [PubMed]

196. Jiménez, A.M.; López de Cerain, A.; Gonzalez-Peñas, E.; Bello, J. Determination of ochratoxin A in pig liver-derived pâtés by high-performance liquid chromatography. Food Addit. Contam. 2001, 18, 559-563. [CrossRef]

197. Frank, H.K. Food contamination by ochratoxin A in Germany. IARC Sci. Publ. 1991, 115, 77-81.

198. Expert Committee on Food Additives (JECFA); Food and Agriculture Organization (FAO); World Health Organization (WHO). Safety Evaluation of Certain Food Additives and Contaminants; Food Additives Series 59; FAO: Genova, Italy, 2008; pp. $357-426$.

199. European Food Safety Authority (EFSA). Scientific Opinion Statement on Recent Scientific Information on the Toxicity of Ochratoxin A. EFSA J. 2010, 8, 162.

200. Boon, P.E.; Bakker, M.I.; van Klaveren, J.D.; van Rossum, C.T.M. RIVM Report 350070002/2009: Risk Assessment of the Dietary Exposure to Contaminants and Pesticide Residues in Young Children in The Netherlands. Available online: https: //www.rivm.nl/bibliotheek/rapporten/350070002.pdf (accessed on 20 October 2021).

201. Jorgensen, K. Occurrence of ochratoxin A in commodities and processed food-A review of EU occurrence data. Food Addit. Contam. 2005, 22, 26-30. [CrossRef] [PubMed]

202. European Food Safety Authority (EFSA). Opinion of the Scientific Panel on Contaminants in Food Chain on a Request from the Commission Related to Ochratoxin A (OTA) as Undesirable Substance in Animal Feed. EFSA J. 2004, 101, 1-36. 